\title{
12th Quadrennial Symposium of the International Association on the Genesis of Ore Deposits (IAGOD)
}

\author{
Moscow, Russia, August 20-24, 2006
}

The 12th Quadrennial Symposium of the International Association on the Genesis of Ore Deposits (IAGOD) was held in Moscow, Russian Federation, August 20-24, 2006. The symposium, which carried the title 'Understanding the Genesis of Ore Deposits to meet the Demands of the 21st Century', attracted about 350 participants, of which 170 came from countries outside Russia and the CIS.

The venue for the symposium was the Russian Academy of State Service, under the auspices of the President of Russian Federation, situated in the southwest of Moscow. The symposium was organised by the Foundation "Science and Our Future", with the local Organizing Committee consisting of Sergei Cherkasov (Executive Secretary), Valery Smolkin (Field Trips), Michael Tokarev (Representative of the European Association of Geoscientists and Engineers, AEGE) and Olga Koshel (Secretary). Supporting organisations included, among others, the International Association on the Genesis of Ore Deposits (IAGOD), the Society of Economic Geologists (SEG), the Department of Earth Sciences of the Russian Academy of Sciences, the Federal Agency for Mineral Resources of the Ministry of Natural Resources of the Russian Federation, Moscow State University, and the Vernadsky State Geological Museum. A 9-member International Advisory Board and a 10-member Local Scientific Committee, the latter representing leading research institutes of the Ministry of Geology and the Russian Academy of Sciences and headed by Academician Dmitry Rundqvist, oversaw preparation of the scientific programme. The International Geoscience Programme (IUGSUNESCO/IGCP), the Russian-French Metallogenic Laboratory (Vernadsky SGM RAS Moscow \& BRGM Orleans), and the Centre

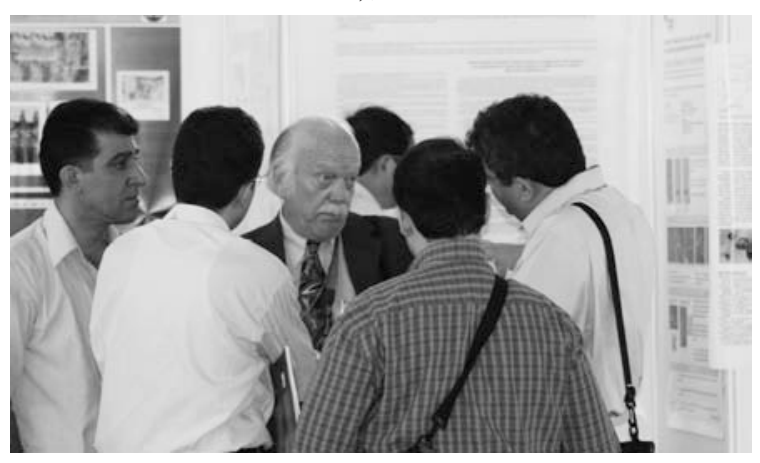

Participants in the 'Ukrainian Carpathians and Ukrainian Shield' excursion examine tectonised Neogene andesites at Chorna gora, near Vynogradiv, Ukrainian Transcarpathians. for Russian and Central Eurasian Mineral Studies (CERCAMS, NHM London) contributed as scientific sponsors. The symposium gratefully acknowledges support by its main sponsors BHP Billiton and JSC MMC "Norilsk Nickel", and the informational sponsors, SRK Consulting, Advantix Ltd./MINEX initiative and Nordeco Eurasia. All of us involved in the symposium are also grateful to the Russian Academy of Sciences, the Russian Federal Agency "Rosnedra" and to VSEGEI St Petersburg, for their support and encouragement.

Following the opening ceremony on the first day of the symposium, a series of plenary lectures sponsored by the Russian Academy of Sciences were given under the title "Global metallogeny and genesis of mineral deposits: From analysis to new methods of economic geology', including lectures by Dimtry Rundqvist ('100 years of metallogeny'), Peter Laznicka ('Pre-, syn- and post-geoscientific sources of industrial metals'), Steven Scott ('Magmatic fluids and 'giant' volcanogenic massive sulphides'), and Anthony Naldrett ('Towards an integrated model for the concentration of PGE in the Bushveld Complex').

A second plenary session 'Mineral deposits of Eurasia and the global perspective' included invited key papers given by Alexander Yakubchuk et al. ('Metallogeny of the Central Asian supercollage: Urals and Tien Shan as key examples'), Douglas J. Kirwin, SEG Lecturer ('The giant Oyu Tolgoi porphyry copper-gold deposit: discovery history and exploration implications, South Gobi'), Sergey Rodionov and Alexander Khanchuk ('Mineral deposits of Siberia and
the Russian Far East'), and Wenjiao Xiao et al. ('Paleozoic-Early Mesozoic accretionary tectonics and metallogeny of the northern Tibetan Plateau').

Following the tradition of the previous IAGOD Quadrennial Symposia, several sessions were convened by the commissions and working groups of IAGOD, including 'Placers and placer-forming ore formations' (Commission on Placer Deposits), 'Sn, W and rare metal magmatichydrothermal systems'-combined with-'Endogenic metallogeny of rare elements: issues for prognosis, prospecting and

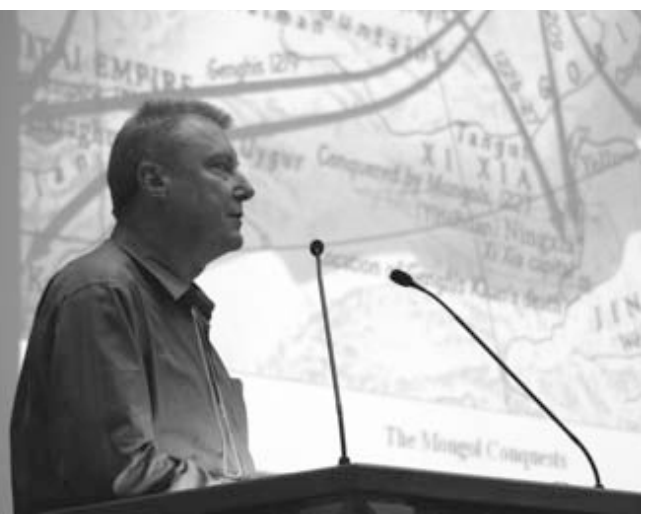

Douglas J. Kirwin, SEG Lecturer, gives his keynote lecture 'The giant Oyu Tolgoi porphyry opper-gold deposit: discovery history and xploration implications, South gobi'.

exploration' (Working Group on Tin and Tungsten Deposits), 'Industrial properties and genetic relationships in industrial minerals and rocks' (Commission on Industrial Mineral Resources), 'Remote sensing tectonics and ore prospecting'.

Subsequent symposium days featured sessions on a wide range of topics, including 'Gold accumulations: processes and ore formation in gold and gold-bearing deposits', 'Traditional and new types of uranium deposits', 'Genesis of diamonds', 'Genesis of gem deposits', 'NE Asia metallogeny and tectonics', 'Black shale-hosted mineral deposits: from their origin to their environmental impacts', 'Traces of heat-and-mass supply for formation of giant ore accumulations', 'IT applications for economic geology (Data bases, GIS, etc.)', 'Deep tectonic processes with super accumulation of metals in lithosphere' and 'Paragenesis - a new challenge to academia and industry'.

No less than five current International Geoscience Program (IGCP) projects active in the field of mineral deposits held scientific sessions at the symposium. Session titles were 'Pt ores: new ideas in origin, prospecting and processing/contact-type PGE deposits' (IGCP-479-Sustainable use of platinum group elements), 'Fluvial palaeosystems: evolution and mineral deposits' (IGCP-514-Fluvial palaeosystems: evolution and mineral deposits), 'Global comparison of modern and ancient VMS deposits' (IGCP-502-Global comparison of volcanic-hosted massive sulphide districts), and 'Au-Ag-Te-Se deposits: modern methods of studying their genesis' (IGCP-486-Au-Agtelluride-selenide deposits). The plenary session 'Mineral deposits of Eurasia and the global perspective' was co-sponsored jointly 


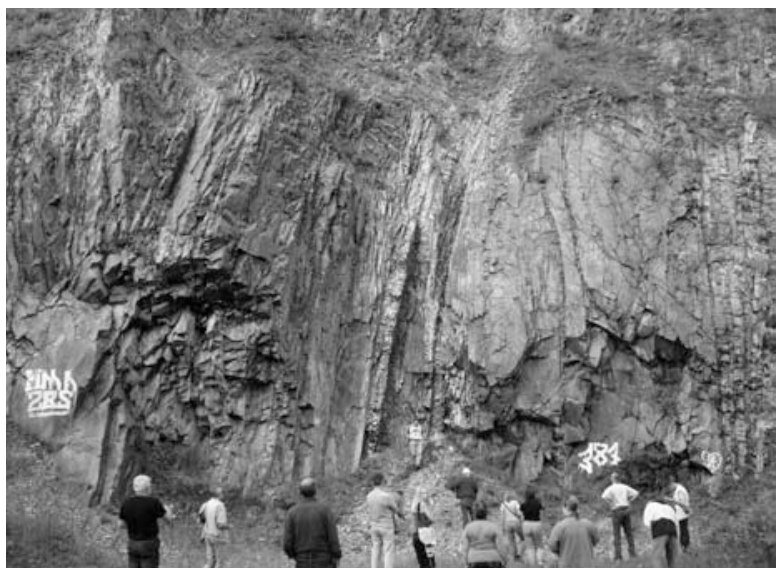

Avid discussion took place during the poster sessions each afternoon of the symposium.

with CERCAMS by IGCP-473 ('GIS metallogeny of Central Eurasia').

The short abstracts were published as a printed volume (Cherkasov, Ed., 2006a), and a total of 385 extended abstracts were published on CD-ROM (Cherkasov, Ed., 2006b). On the occasion of the symposium, the Russian-French Metallogenic Laboratory launched one of its novel products for discounted distribution also through IAGODa CD-ROM "Largest Mineral Deposits of the World" (Rundqvist et al., 2006),

A series of field trips were offered before, and after the symposium. These trips were designed to show participants some of the most important ore districts in Russia, and most excursions were heavily booked, with some interested persons unable to find a place. The pre-symposium excursions offered were: 'The Monchegorsk ore district, Kola Peninsula', 'Ore deposits and occurrences in the North Ladoga Region, Southwest Karelia', 'Ore facies and lithogenesis of massive sulphide deposits of the Middle and North Urals' and 'Geology and ore deposits of the Noril'sk ore district'. Post-symposium field trips were 'Volcanic-hosted massive sulphide deposits of the South Urals', The Onega ore district, Central and East Karelia' and 'Diamond placer deposits of the Krasnovishersk District, Perm Region'. A 191page excursion guidebook, in full colour, containing details from all the trips was published to coincide with the symposium (Smolkin, Ed., 2006). A further group preceded the symposium by participation in a field workshop 'Ukrainian Carpathians and Ukrainian Shield', organised by the Ukrainian National Group of IAGOD. A separate volume has been published in the IAGOD guidebook series (Bobrov et al., 2006).

IAGOD also held its biannual Council meeting in Moscow. the follow-up IAGOD General Assembly elected Academician D. V. Rundqvist as an Honorary Life member of IAGOD, as well as approving the nomination of Adelaide, South Australia, as the venue for IAGOD's 13th Quadrennial Symposium in 2010 .

\section{References}

(all publications are available from the IAGOD Publications Manager at the address given below)

Cherkasov, S. V., (Ed.), 2006a, Program and Short Abstracts, 12th Quadrennial IAGOD Symposium, 130 pp., "Science and Our Future" Foundation, Moscow, 2006 (GBP 10.-).

Cherkasov, S.V., (Ed.), 2006b, Extended Abstracts, 12th Quadrennial IAGOD Symposium, CD-ROM. "Science and Our Future" Foundation, Moscow, 2006 (GBP 20.-).

Smolkin, V. F. (Ed.), 2006, Field Trip Guidebook, 12th Quadrennial IAGOD Symposium, 191 pp., "Science and Our Future" Foundation, Moscow, 2006 (GBP 40.-).

Bobrov, O. B., Cook, N., Gurskyi, D.S., and Malyuk, B.I. (Eds), 2006, Ukrainian Carpathians and Ukrainian Shield, 154 pp., IAGOD Guidebook Series Vol. 15, Kyiv-Lviv: ZUKC, 2006 (GBP 50.-).

Rundqvist, D., Cassard, D., Cherkasov, S., Tkachev, A., Gatinsky, Yu., Shalimov, I., Arbuzova, E., Vishnevskaya, N., Gateau., C. and Husson, Y., 2006, Largest mineral deposits of the world. NavigaSIG Large and Superlarge Deposits v. 1.0, CD-ROM, Russian French Metallogenic Laboratory, Moscow, August 2006. ISBN 5-9900765-1-7 (GBP 100.-).

Dr. Sergei Cherkasov

IAGOD LOC Executive Secretary

Vernadsky State Geological Museum of RAS 11-2 Mokhovaya str., Moscow, 125009 RUSSIA

Tel.: (+7) (095)-203-4667

Fax: (+7) (095)-203-5287

E-mail:sergy@sgm.ru

\section{Prof. Nigel Cook}

IAGOD Secretary General

NHM/Geologisk Museum

University of Oslo

Postboks 1172-Blindern 0318 Oslo NORWAY

Tel. (+47) 22851787

Fax: (+47) 22851800

E-mail:nigelc@nhm.uio.no

Dr. Reimar Seltmann

IAGOD Publications Manager

CERCAMS

Dept. Mineralogy, Natural History Museum

Cromwell Road, London $U K$

Tel: $(+44) 2079425042$

Fax: (+44) 2079426012

E-mail:R.Seltmann@nhm.ac.uk

\section{INQUA Congress 2007}

Caines Convention Center, Australia

28 July-3 August 2007

\section{Quaternary Climate Change}

Paleoenvironmental Reconstruction

Geomorphology and Landscape Evolution

\section{Archaeology}

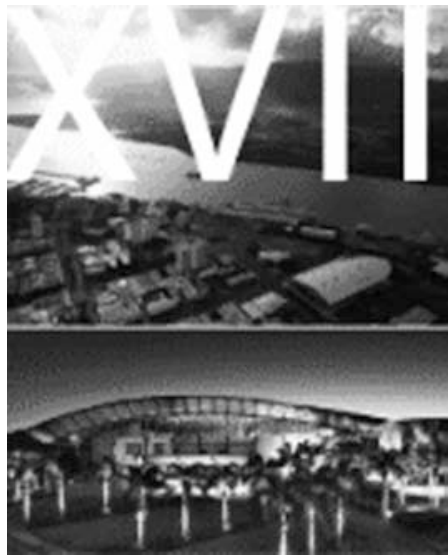

For further information see the Austrasian Quaternary Association's webpage at: http://www.aqua.org.au/AQUA/INQUA2007.html 


\title{
21 st Colloquium on African Geology-CAG21
}

\author{
Maputo, Mozambique, July 3-5, 2006
}

Under the auspices of the Geological Society of Africa (GSAf), the Geological Mining Association of Mozambique (AGMM) organized the 21st Colloquium on African Geology under the theme "Geoscience for Poverty Relief". The Geological Society of South Africa (GSSA) was also involved into the organization of the event by setting-up the pre-CAG21 geological excursion from Johannesburg to Maputo. This cooperation between two sister societies from two neighboring countries in organizing an international event was highly appreciated and is regarded as a step for implementing and developing the policies for regional cooperation.

The program comprised a plenary session, several parallel technical sessions, workshops and poster sessions during the three days of the event, and geological excursions.

The event was attended by 300 delegates from 52 countries, and was held at the International Conference Center Joaquim Chissano in Maputo.

Opening and Closing Ceremonies were chaired respectively by the Minister and Vice-Minister of Mineral Resources of Mozambique, Mrs. Esperanca Bias and Mr. Abdul Razak Noormahomed. The meeting was also honored by the presence of the President of the Republic of Mozambique, Mr. Armando Guebuza, who addressed an important communication to the audience, where he expressed the major importance the Government of Mozambique gives to the role of Geosciences for the development of the Country. An important plenary session was organized to welcome His Excellency Armando EmIllio Guebuza, President of the Republic of Mozambique as Patron of the Meeting. After welcoming addresses by the Presidents of AGMM and GSAf and the Minister of Mineral Resources of Mozambique, the President of the Republic gave an important communication on the important

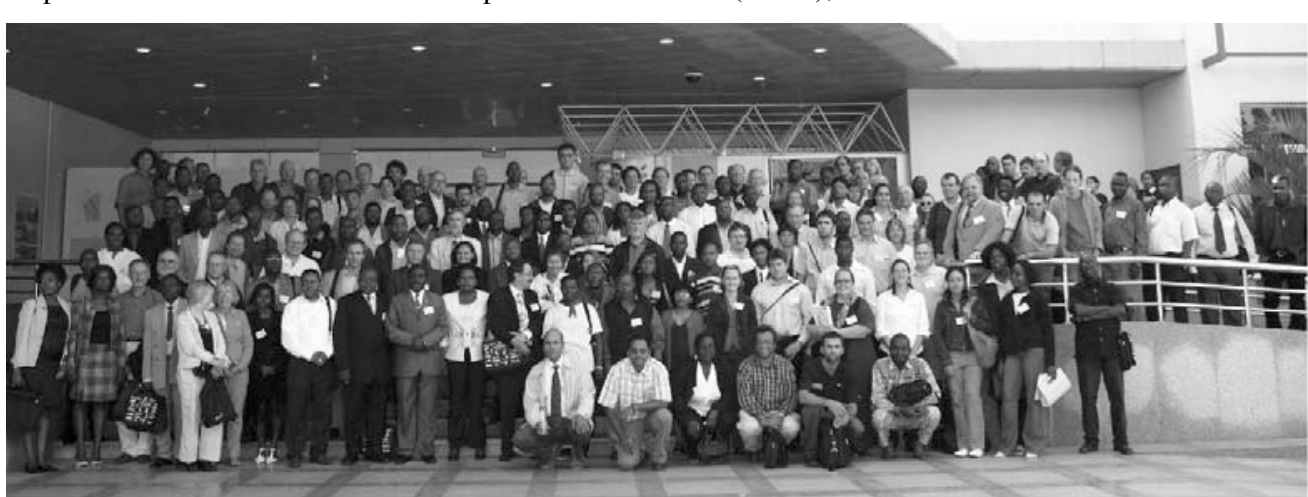

Family Photo at the Conference Center. Photo by José Esmae.l role that geoscience plays in the development of Mozambique.

As a matter of special reference, the President of the Republic welcomed the presence in Maputo of several international geoscience organizations, such as IUGS, IYPE and CGMW, showing the relevance these organizations give to the Maputo event.

The Plenary Session continued with the following presentations:

- Ed de Mulder, Chairman of the Board of Officers of the International Year of Planet Earth, proclaimed by the United Nations, who presented the objectives of the YEAR;

- Jean-Paul Cadet and Philippe Rossi reported on work carried out by the Commissions of the Geological Map of the World and of the Tectonic Map of Africa;

- Hongren Zhang, President of IUGS, presented the Union and its international projects, including the IUGS-UNESCO International Geoscience Project (IGCP).

The program included 210 technical papers presented in 27 parallel sessions, focusing on the following topics: Earth resources and sustainable development in Africa, Environment, Geochemistry \& Geochronology, Geodynamics, Geodynamics of Africa, Geoeducation, Geohazards, Geophysics, Medical geology, Paleoclimatology \& human evolution in Africa, and miscellaneous. One of the technical sessions was dedicated to the results of the mapping program carried out in Mozambique during the last 4 years, covering the whole country with 1:250.000 geological maps, with some areas mapped to 1:50.000.

The 41 posters were presented in two sessions, focusing on the same topics as above.

Several workshops on the following topics were also organized:

- Geohazards,

- International Union of Geological Sciences (IUGS),

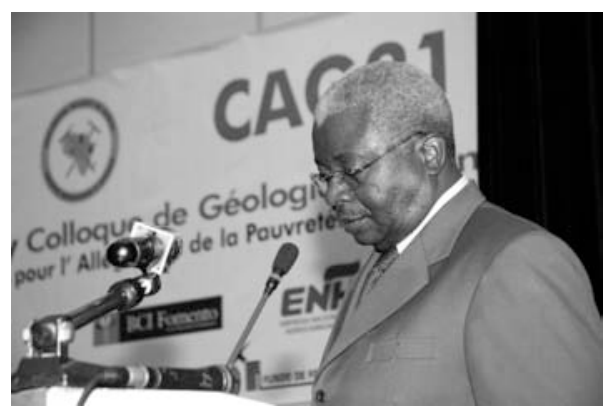

Mr. Armando Guebuza, President of the Republic of Mozambique, addressing to the Delegates. Photo by José Esmael.

- IUGS Commission for the Management and Application of Geoscience Information,

- The SIG-Africa Network Pilot Project: creation of a geoscientific information network to aid sustainable development in Africa-chaired by BRGM,

- Medical geology and inaugural meeting of the Africa Association of Medical Geology,

- Inkaba ye Africa, discussing issues related to the research of Earth History back to 200 M.y. to facilitate a better planning into the future.

During the session of Tuesday 4, the President of the Republic handed over the Shackleton Award to Mrs. Pacifique Kampunzu, widow of the recipient, Prof. Henri Kampunzu, in recognition of his work on Precambrian geology in Africa.

It is important to mention the Maputo Declaration on the Development of Geosciences in Africa adopted at the Closing Ceremony and to be distributed as widely as possible in Africa and around the world. The text of this declaration is available at the end of this notice.

Just before the Closing Ceremony the Geological Society of Africa realized its General Assembly, where discussions and decisions were taken concerning future meetings, society matters, publication of CAG21 material in the JAES, amongst others.

The program also included preand post-colloquium excursions. As said above, the pre-CAG21 excursion "Big Five GeoSafari" was organized by GSSA, with visits to important South African gold, diamond, coal, platinum, chrome, and copper mines. Visits also included the geology of Witatersrand Basin, Karoo Basin, Bushveld Complex and Phalaborwa. Geosites in the area of the Kruger National Park were also visited. 


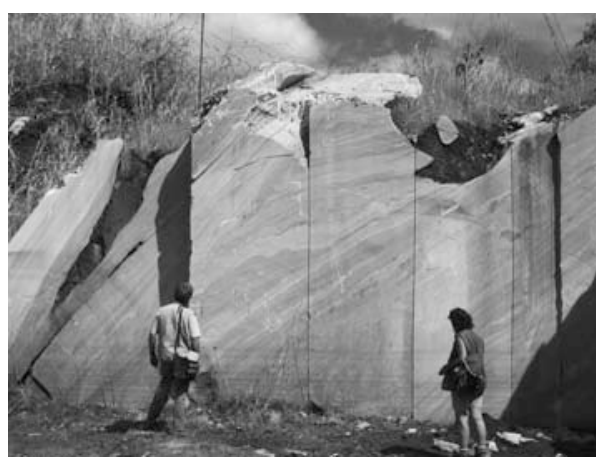

Montepuez Marbles in Cabo Delgado. Photo by Jan Sandstad.

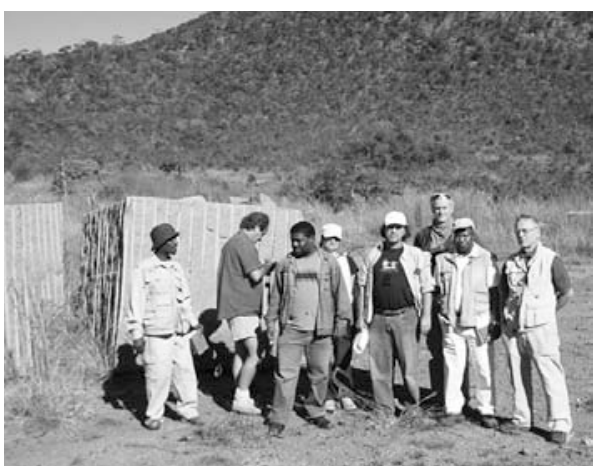

Participants to Manica Excursion. Photo by Olavo Deniasse.

Post-CAG21 excursions in Mozambique were organized by AGMM and included visits to the northern provinces of Cabo Delgado and Nampula, the central province of Manica and the southern province of Maputo.

The Cabo Delgado excursion was mainly oriented to Precambrian, with a visit to Cretaceous sediments of the Rovuma Basin. Delegates visited the Precambrian rocks of the Neoproterozoic age and PanAfrican Orogeny: Chiure Supergroup and Lúrio Belt. The visit to the Rovuma Basin focused on the various types of calcareouscemented sandstones. Attention has been also paid to oil seeps along the Pemba bay.

People attending the Nampula excursion visited the Meso-proterozoic of NE Mozambique, mainly formations from the Nampula Sub-Province and the Monapo Complex. Participants also visited the Fortress and Palace-Museum of the Island of Mozambique.

The excursion to Manica focused on the Archaean Manica Greenstone Belt (Zimbabwean Craton), the Proterozoic rocks of Gairézi and Báruè and the Cretacic Xiluvo Carbonatite. Delegates were also able to see aspects of artisanal gold mining in the area.

Excursion to Maputo included the volcanics of the Libombos Mountains, along the border to South Africa and Swaziland, the intrusion of Vergueiros, the sedimentary formations of Cretacic, Tertiary and Quaternary age, west and south of Maputo.

Exposition booths were organized for 26 organizations, of which 10 from Mozambique and 16 from overseas.

The Social Program included an Ice Breaker at the Fortress of Our Lady of Con-

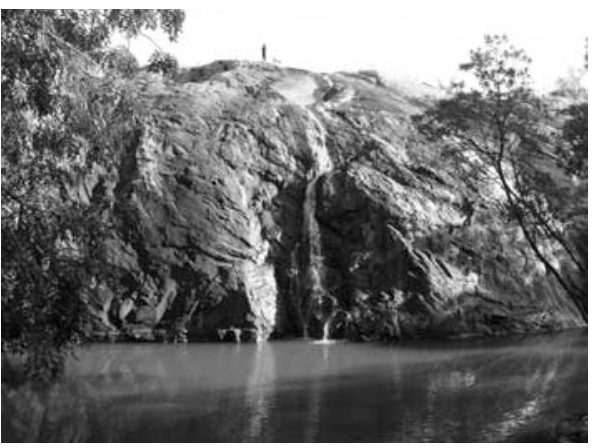

Namaacha Rhyolites, Libombos Mountains. Excursion to Maputo. Photo by Amad Mamad.

ception, the point where Maputo was founded by the Portuguese in the 16th century. Delegates were welcomed to Maputo by a representative of the Maputo City Mayor. A Gala Diner was also organized at the Kaya Kwanga restaurant with a show of traditional dances, by the Group Milorho, and the famous Mozambican singer Mingas and her Band. People danced but were also tempted to watch the World Cup Semi-Final Germany-Italy!

\section{Lopo Vasconcelos}

President of AGMM and of the LOC of CAG21 Dept. Geologia/Dept. Geology

Universidade Eduardo Mondlane University Maputo

Mozambique

System for Africa (AEGOS) initiative to develop a digital, distributed, shared and interoperable information system for the ACP subsurface, resources and hazards;

Invite African geosciences community and civil society to contribute actively, through National Committees of the International Year of Planet Earth (IYPE), to demonstrate the great potential of the geosciences in building a safer, healthier and wealthier Africa;

Invite Leaders of the African nations to recognise fully and give a special support to the development of the geosciences throughout the continent, particularly by increasing national research budgets and, more specifically, by giving special attention to the alarming brain drain, which is strongly weakening African research system;

Call upon the African Union, through its relevant Specialized Technical Committee and African sciences and technology ministers to develop a Strategic Plan for a Balanced Development of the Earth Sciences in Africa, and specifically, to ensure that Africa's Science and Technology Consolidated Plan of Action include the geosciences.

Maputo, July 5, 2006
- Convinced that geoscience's knowledge can help Africa learning from past misenergy and water resources and in lenges that face the continent;

Remind African geoscientists of their responsibilities in studying their continent so as to make the north-south partnership stronger and more fruitfu;

Support the Africa, Caribbean, and Pacific (ACP)-European Union Georesources 


\title{
Third Conference of the Association of African Women Geoscientists - "Women, Geosciences and Development"
}

\author{
El Jadida, Morocco, May 6-11, 2006
}

\begin{abstract}
A better understanding of the geology and mineral potential of Africa is important in the overall context of social and economic development across the continent. Since 1995 the Association of African Women Geoscientists (AAWG) has existed, holding biennial meetings since 2002, with the aim to encourage women geoscientists to participate in Earth Sciences-related conferences, as well as to inform or become involved on gender issues related to the Earth Sciences.
\end{abstract}

\section{Introduction}

Why organize a conference dedicated especially to Women geoscientists? It was noted that during most geological meetings, the participation of women geoscientists is typically very limited. This is partly due to the presence of a small number female geoscience graduates on the continent. In order to rectify this discrepancy, a decision was taken to form an association. In 1995, at the Nairobi conference of the Geological Society of Africa (GSAf), the Association of African Women Geoscientists (AAWG) was created. This Association believes that the involvement of women in education and research in earth sciences is a key factor to help Africa solve its socio-economic problems. As an Association, we believe that women can play an important role in the sustainable development of their respective countries through their multiple capacities as mothers, teachers and researchers.

The objectives of the Association of African Women Geoscientists (AAWG) include providing a forum for discussion, dissemination of information and cooperation between women geoscientists, organizations and socio-economical stakeholders engaged in African geosciences. Building on this, the AAWG decided to hold its first international meeting in 2002 for the purpose of exchang-

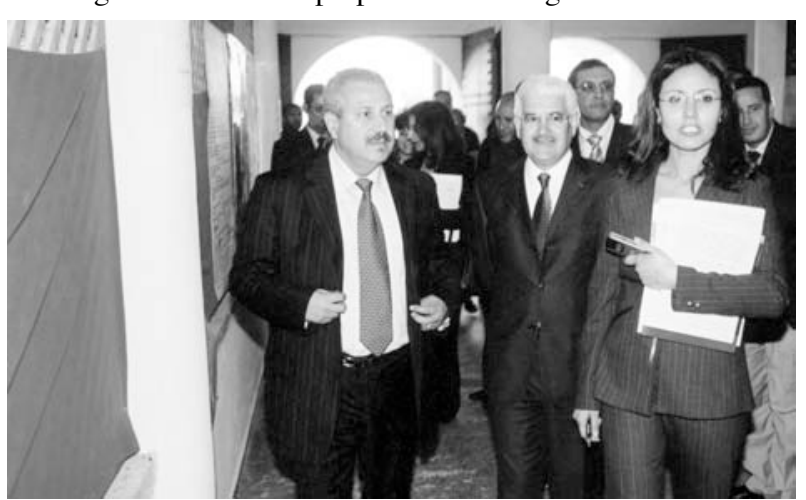

CAAWG Opening Ceremony. Left to right, Mohammed Boutaleb (Minister of Energy and Mines), the El Jadida Governor and the chairperson of the Conference. ing ideas, discussing results and encouraging women geoscientists from all over the world to present their work at scientific meetings. From the first workshop of the AAWG at Dar Es Salaam, Tanzania, in 2000, to its first and second international conferences (2002 in Cape Town, South Africa, and 2004 in Kampala, Uganda), these biennial meetings have fortunately increased in number of participants as well as in demonstrating that women geoscientists have the capacities and capabilities to provide tools for sustainable development on the African continent.

It is a great honour for the Geology Department of the Faculty of Sciences of the Chouaïb Doukkali University in El Jadida, to host the 3rd Conference of the Association of African Women Geoscientists which was actually organised on the eve of the commencement of the UN-proclaimed International Year of Planet Earth (IYPE). The IYPE is a joint initiative of the International Union of Geological Sciences (IUGS), UNESCO, Geo-Unions (e.g. IUGG, INQUA, etc.) and the Geological Society of Africa whose representatives were present during this conference.

The presence of Minister of Energy and Mines at this conference clearly indicated the great importance that is given to this special event by the Moroccan authorities at the highest level.

We were also honoured by the presence of Bureau members of the International Union of Geological Sciences. This is the first ever meeting of the IUGS Bureau to be held in this region of Africa! Thus, their presence testifies to the strong IUGS commitment to promote Earth Sciences in Africa.

This third conference was attended by more than 150 earth scientists who mostly came from the African countries, and included some geoscientists from Europe, Asia and America.

This scientific event comprised:
Technical sessions in El Jadida (6-8 May 2006)

Technical sessions with oral and poster presentations and seven conferences were given by participants from Algeria, Canada, USA, France, Belgium, Kenya and Morocco.

For this 3-days of meeting about 150 participants assembled in the morning of 6 May 2006 in the lecture theatre of the Faculty of Science of Chouaib Doukkali University in El Jadida for the Opening Ceremony, which lasted till lunch time and included welcome addresses by the Minister of Mining of Morocco, the Director of the National Office of Hydrocarbon and Mines (ONHYM), the General Secretary of the Minister of National Education, Higher Education and Scientific Research, the Governor of the El Jadida Province, the President of IUGS, the President of the Chouaib Doukkali University, the Dean of Faculty of Science, the Dean of Faculty of Letter and Human Sciences and the organizer of the meeting, Prof. Ezzoura Errami. After the Official opening Ceremony, three keynote speeches were also presented, by Prof. Peter Bobrowsky, the General Secretary of IUGS, "Africa and the International Union of Geological Sciences", Prof. Brigitte Senut of the Museum d'Histoire Sciences Naturelle of Paris, "L'éducation en Géosciences par les musées: une aide au développement durable", and Prof. Thomas Schlüter, Programme Specialist of Earth Sciences in the UNESCO Nairobi Office, "A geological Atlas of Africa".

The afternoon of 6 May was followed by technical sessions, in which topics of environmental geology, hydrogeology and Quaternary geology were presented by various participants. The next day's morning session was concerned with orogenic cycles, ore deposits and gem minerals and began with 


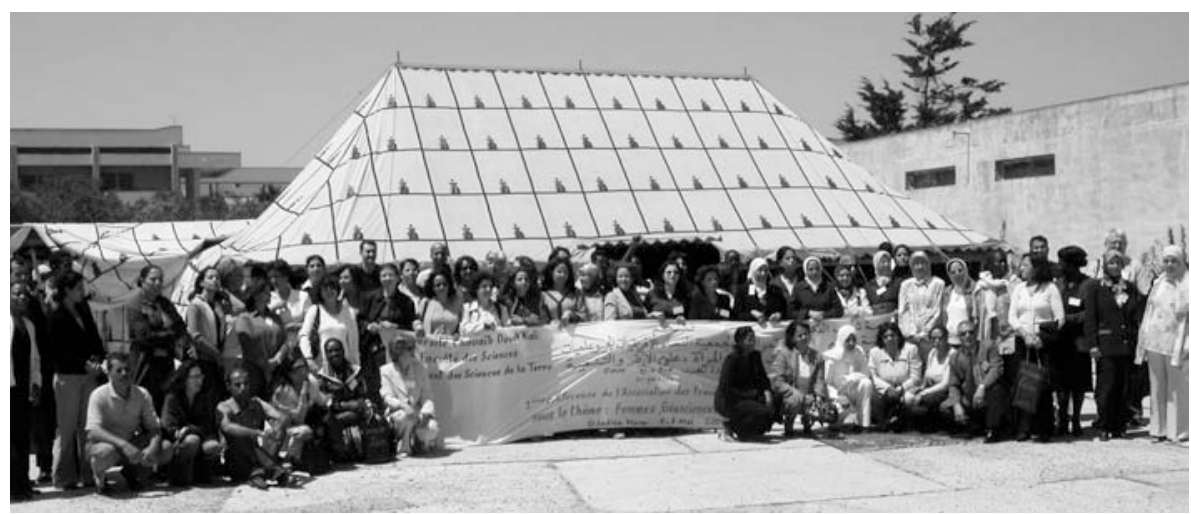

Group photo of the CAAWG3 participants in front of the traditional caïdal tents where the lunch was served.

keynote speeches presented by Prof. Abla Azzouni, "Synthèse sur le magmatisme Précambrien d'Algérie"; Prof. Eldridge Moores, "Precambrian Ophiolites: their Tectonic and Environmental Significance"; Prof. Abdellah Mouttaqi, "Relations géodynamique- minéralisations. Cas du Néoprotérozoïque marocain". The afternoon of the 7th May was followed by a session on geoinformation technology, petroleum geology, geophysics, stratigraphy and palaeontology.

On 8 May, the morning session comprised topics on geological heritage, archaeology and archeomagnetism, and also on earth sciences and development. This session began with a key speech given by Prof. Dominique Laduron, "L'archéométrie au service de l'étude des céramiques archéologiques: objectifs, méthodologies et études de cas".

In addition to oral presentations, about 40 posters were displayed. Both oral and poster presentations precipitated many animated discussions.

Socially and culturally, the meeting was accompanied by Moroccan lunches prepared on the Faculty campus under huge traditional Caïdal tents, a royal gala dinner in a typical Moroccan old palace in El Jadida, on the 7th May 2006 and a guided visit was organised to El Jadida and Azemmour old cities.

\section{Post-conference field excursion (9-11 May 2006)}

A 3-days post-conference field trip through the Moroccan orogenic belts (Pan-African, Variscan and Atlasic orogenies) was organized after the conference (9-11 May 2006) where fascinating geological outcrops were enjoyed. The excursion began with a visit to the Cretaceous-Tertiary phosphates Gantour mine close to the Imperial Marrakech City. The phosphates are of a great economic as well scientific interest. The Moroccan phosphate deposits form an homogeneous set, the "Phosphate series". This latter consists of an alternation of friable or compact phosphate horizons, and barren beds of varied lithology: sandstone, clays, marls, limestone, flint and flinty limestone, sometimes with more or less phosphate. The ensemble is capped by an important carbonate and siliceous flag- stone called "Dalle à Thersithées" by reference to the gastropods it contains.

The old Bir Nhass Zinc mine and the Sidi Bou Othmane old graphite district (also called "Frag Elma") are located in the central Jebilet $c a .30 \mathrm{~km}$ north of Marrakech, which consists of Palaeozoic terrains. The central part of this area is characterized by an intense metamorphism. The limestone lenses are transformed to grenatites, but the majority comprise irregular masses of grenatites and marble. The grenatites are composed of calcite, diopside, idocrase, wollastonite, epidote (clinozoïsite). The graphite is irregularly distributed in the metamorphic limestone; however, it is preferentially concentrated in the contact zone with the schists. Graphite concentrations appear also sometimes along the faults affecting the limestone lenses. In January 1950 , the estimated reserves were approximately $20,000 \mathrm{~T}$ of the graphite ore deposit which correspond to $3000 \mathrm{~T}$ of commercial concentrates $30-50 \%$ of graphite.

The High Atlas which extends from Agadir to eastern Tunisia consists of a horst which is tectonically and stratigraphically related to the development of the Atlantic margin. Their northern and southern flanks are occupied by Cretaceous, Jurassic (terrigenous clastic materials, limestone and olistostromes) and Triassic rocks (mudstones with intercalated evaporates and tholeiitic dolerites). The central part of the High Atlas is occupied by Neoproterozoic and Paleozoic rocks. The subsidence ended after the Turonian and from the late Cretaceous the Atlas began to rise. Border faults developed into thrust faults, along which slices of Mesozoic strata were thrust onto the adjoining platforms. The excursion ended up in the Neoproterozoic terrains of the Anti-Atlas.

\section{CAAWG4 venue}

For the next meeting of the association, 3 country-candidates offered applications: Cameroon, Egypt and Senegal, of which Egypt was overwhelmingly elected to organize the fourth conference of the Association of African Women Geoscientits. The present AAWG Council Members and all CAAWG3 participants enthusiastically approved that the fourth Colloquium (CAAWG4) will be held in Cairo (Egypt) in 2008.

\section{Conclusion and perspectives}

Two major publications should result from this conference: 1) a special issue in English of the Journal of African Earth Sciences Elsevier "The African Geology through women geoscientits", guest edited by E. Errami, A. Segueti and L. Meck; 2) A Special volume in French in Notes et Mémoires des Services Géologiques du Maroc "Femme, Géosciences et Développement durable".

This conference has led to some new initiatives to participate to the development of the African local populations.

1. Two proposals of IGCP projects will be submitted, with the provisional titles: i) "Geoparks in Africa and local sustainable development", ii) "environmental problems in Africa". This project will deal with the impacts of the pollutants on water quality and chronic diseases.

2. Creation of the Moroccan Association of Women Geoscientists.

3. In order to promote the Geosciences, a decision was taken to organize an outreach day in Roumania and in every African country especially in Zimbabwe, Ivory Cost and Morocco.

Lastly, we wish to express through this conference report our greatest hope and impact that will come from this ConferenceMore women will undertake earth science education for the benefit of society, more women will take up leadership roles in earth sciences and many more women will present their findings to international conferences. We would like also to make a special observation and concern for women, all over the world, who did not get opportunity to go to school! We should not forget them!

\section{References}

Piqué, A., 2001,Geology of Northwest Africa. IXIV, 1-310; Gebrüder Bornträger, Berlin, Stuttgart.

\section{Ezzoura ERRAMI}

Chairperson of the Conference

Département de Géologie, Faculté des Sciences B.P. 20, 24 000, El Jadida

MOROCCO

errami@ucd.ac.ma,erramiezzoura@hotmail.com 


\title{
"Ancient Life and Modern Approaches" \\ -Second International Palaeontological Congress (IPC2006)
}

\author{
Beijing, China, June 17-21, 2006
}

The Second International Palaeontological Congress (IPC2006), a remarkable event known in the public media as the "Olympic Games of Global Palaeontologists", was successfully held from June 17-21, 2006 at the Peking University (PKU), Beijing, China. Approximately 800 participants from 40 different countries attended this great event, including 403 participants from outside China. The participating countries included Argentina, Austria, Australia, Belgium, Brazil, Canada, China, Czech Republic, Denmark, Egypt, Germany, Finland, France, Hungary, India, Iran, Italy, Latvia, Lithuania, Japan, Korea, Malaysia, Mongolia, the Netherlands, New Zealand, Namibia, Norway, the Philippines, Poland, Portugal, Russia, Spain, Sweden, Switzerland, Thailand, the United States of America, the United Kingdom, the United Arab Emirates, and Viet Nam.

Many distinguished guests attended the opening ceremony, including representatives of sponsoring organizations, and of international academic organizations. Among those present were Zhou Guangzhao and Deng Nan (China Association for Science and Technology), Chen Yiyu (National Natural Science Foundation of China), Li Jiayang and Fu Bojie (Chinese Academy of Sciences (CAS)), Zhang Xian'en (Ministry of Science and Technology), Zhang Hongren (International Union of Geological Sciences), Zhang Meeman, John Talent and Richard Aldridge (International Palaeontological Association (IPA)), Yang Zunyi and Wang Hongzhen (China University of Geosciences, Beijing), Li Xingxue (Nanjing Institute of Geology and Palaeontology, CAS) and representatives from the Palaeontological Society of China and Geological Society of China. Deng Nan, Li Jiayang, Zhang Hongren and Richard Aldridge delivered opening addresses at the congress; Lin Jianhua (Peking University) and Sha Jingeng (Nanjing Institute of Geology and Palaeontology, CAS and Palaeontological society of China) also spoke at the opening ceremony.
The quadrennial International Palaeontological Congress (IPC) is the official gathering of the IPA. It represents the highest level of academic conference for palaeontology in the world. The first IPC was held very successfully in 2002 in Sydney, Australia. The IPC2006 was organized by the Palaeontological Society of China; Nanjing Institute of Geology and Palaeontology, CAS (NIGPAS); the Institute of Vertebrate Palaeontology and Palaeoanthropology, CAS (IVPP); and the School of Earth and Space Sciences, Peking University. Coorganizing universities and institutions were: China University of Geosciences (Wuhan and Beijing); State Key Laboratory of Palaeobiology and Stratigraphy, NIGPAS; Research Center of Palaeontology and Stratigraphy, Jilin University; China Geological Survey (CGS); Institute of Geology, Chinese Academy of Geological Sciences; Beijing Natural History Museum; Geological Museum of China; Northwest University (Xi'an); and China Dinosaur Park (Changzhou).

\section{Scientific sessions}

The five-day congress focused on a series of scientific sessions and symposia discussing new research findings on fossil organisms, with emphasis on the theme "Ancient Life and Modern Approaches". The eight plenary talks presented at the IPC2006 were selected to show case new findings, new approaches and research frontiers in palaeontology. The topics covered: The Cambrian radiation (Douglas $\mathrm{H}$. Erwin, Smithsonian Institution, USA), Molecular taphonomy (Derek E.G. Briggs, Yale University, USA), The greening of Earth and its consequences (Dianne Edwards, University of Cardiff, UK), Secrets of Cretaceous flowers unravelled by X-ray tomography (Else Marie Friis, Swedish Museum of Natural History, Sweden), Molecular evidence for radical changes in ocean chemistry (Roger Summons, Massachusetts Institute of Technology, USA), The greatest end-Permian catastrophic events (Shen Shuzhong, NIGPAS, China), New dis- coveries of the Jehol Biota (Zhou Zhonghe, Institute of Vertebrate Palaeontology and Palaeoanthropology, CAS, China) and The fish-tetrapod transition (Per E. Ahlberg, Uppsala University, Sweden).

The congress held five Special Sessions and 30 General and Topical Sessions, during which more than 505 oral talks and 200 posters were presented. The contributions to the sessions reflected the most recent progress, discoveries and results, and new methods and techniques in a variety of research fields and directions across palaeontology. The Special Sessions covered: 1) palaeoembryology and developmental biology in Earth history; 2) geo-biodiversity: taxa, morphology and ecology; 3) evodevo: palaeontology and evolution; 4) past and present global changes and biotic saltations. The research results presented and discussions held in the General Sessions covered a wide range of disciplines in palaeontology, including paleobotany and microflora, invertebrate and vertebrate paleontology, fossil lagerstaetten, trace fossil and ichnofacies, paleoecology, palaeobiogeography, palaeogeography and palaeoclimate, high-resolution and high-impact biostratigraphy, integrative stratigraphy, palaeoanthopology and micropalaeontology.

A remarkable feature of this congress was that the series of international cooperative projects (such as IGCPs) sponsored by the UNESCO and IUGS were included as topical sessions in the congress. The aims of the sessions were to discuss frontier science, focused around important aspects of geology and palaeontology, as well as the evolution of biodiversity during geological history. The major topics included: Earliest evidence of life on Earth, Neoproterozoic palaeobiology and geobiology (IGCP 512); Cambrian radiations and extinctions; Ordovician World: temporal and spatial changes in physical and biotic environments (IGCP 503); Middle Paleozoic vertebrate biogeography, palaeogeography and climate (IGCP 491); Early vascular plant diversity and environmental interactions; Devonian
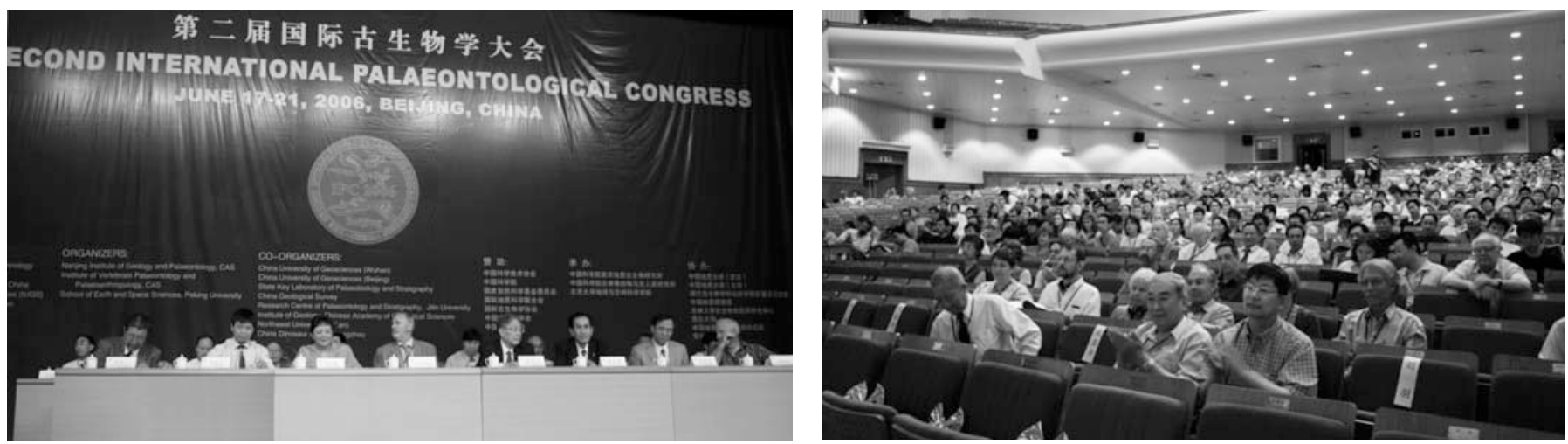

The opening ceremony held at Peking University, Beijing on June 17, 2006. 


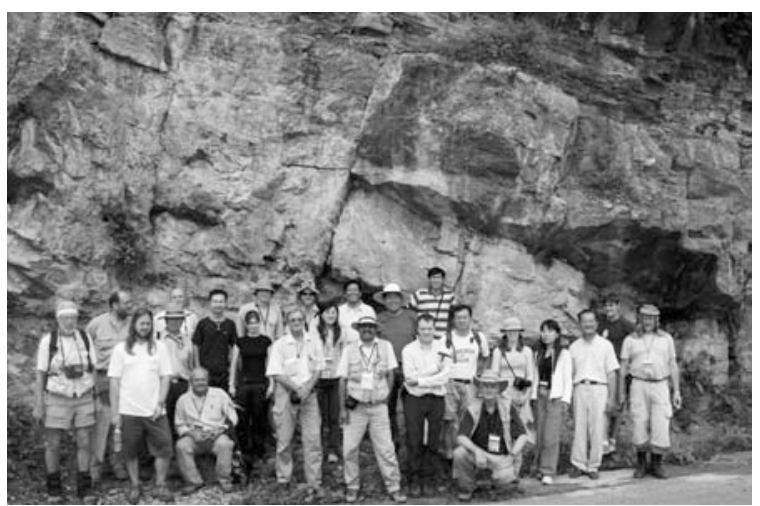

Field excursion at Yichang of Hubei, Yangtze Gorges area for Pre-Cambrian biota and strata.

land-sea interaction: evolution of ecosystems and climate (IGCP 499); Late Paleozoic: the end-Permian extinction following a 100 m.y. long stability; Triassic marine vertebrates and marine ecosystem, Life and environment of Triassic Time (IGCP 467); Marine and nonmarine Jurassic: biodiversity and ecosystems (IGCP-506); Reconstructing the Lower Cretaceous terrestrial ecosystem-evidence from the Jehol Biota in China and its lateral equivalents in other areas; Dawn of the Danian (65-61 Ma) (IGCP 522); Cretaceous biota and K/T boundary in the Heilongjiang River area and its adjacent regions; Neogene climate, biodiversity change and ecosystem; Mammals: phylogeny, divergence and biogeography; Ancient molecules and isotope signals: methodology and application; The evolutionary history of vent, seep and other chemosynthetic ecosystems; Evolution of the pelagic realm; Stratigraphy of orogeny belts; and The past, present, and future of palaeontology in China. In addition, two workshops were held: 'Palaeontological education in universities and museums in the 21st century' and 'Palaeontological parks: the worldwide conservation of outstanding fossil sites'

Nearly 700 abstracts were received, reviewed and included in a special volume entitled "Ancient Life and Modern ApproachesAbstracts of the Second International Palaeontological Congress" published by the University of Science and Technology of China Press (Editors: Qun Yang, Yongdong Wang and Elizabeth A. Weldon).

The congress also hosted a number of business meetings for the IGCP projects, the IPA General Assembly, and the International Subcommission on the Permian System, and the Second National Committee Meeting of the Scientific Terms of Palaeontology in China.

\section{Field excursions}

About ten pre-congress, mid-congress and post-congress field excursions were organized for participants to examine the best-exposed strata of well-preserved fossil localities in China. The main pre- and post-congress excursions included: 1) The Devonian of the GuilinXiangzhou area, South China: stratigraphy and sedimentology; 2) Permian-Triassic sections from shallow marine, slope to intra-platform basin in the eastern part of South China; 3) The Early Cretaceous Jehol Biota of northern China: feathered dinosaurs, basal bird, mammals and angiosperms; 4) The Cryogenian and
Ediacaran of South China: Ice ages, Animal Embryos, Acritarchs, and Algae; 5) the Neoproterozoic and Cambrian Stratigraphy and Fossil-Lagerstaetten of Guizhou and Yunnan Provinces; 6) Upper Palaeozoic to Triassic successions of the Tibetan Himalayas and significant geological occurrences along the road leading to the Himalayas; 7) Classic sites of continental Tertiary in Inner Mongolia, China; 8) Triassic marine-vertebrate palaeontology and stratigraphy of the GuizhouYunnan Plateau, southwestern China. The mid-congress excursions included visits to: 1) Zhoukoudian in the suburb of Beijing: the cave home of Peking Man; 2) Cambrian and Ordovician successions in Xishan of Beijing; 3) Exhibition of marine Triassic vertebrate fossils from Guizhou and Early Cretaceous Jehol biota in the Geological Museum, Beijing; and 4) an exhibition of fossil collections in the Beijing Museum of Natural History. Participants were impressed not only by the well exposed strata but also by the exceptionally preserved splendid fossil biota in China.

\section{Exhibits on books and journals}

During IPC2006, a number of well-known scientific publishers, including Elsevier, Blackwell, Cambridge and Science Press (China) displayed samples of their new books and journals on geosciences, focussing on those related to palaeontology and stratigraphy. Some of the publishers, such as Blackwell and Palaeoworld, arranged editor-author meetings or editorial board meetings during the congress.

\section{Social program}

A variety of social activities were held during the congress, including a reception hosted by the vice-president of PKU, Lin Jianhua, and the congress banquet which included cultural entertainment hosted by representatives of the major organizing institutions: Jingeng Sha of NIGPAS and Min Zhu of IVPP. William Schopf (University of California, Los Angeles) was invited to give the audience an amusing discourse on "Palaeontological riches of China: One visitor's impressions". Cultural tours to historical sites in Beijing, such as the Great Wall and the Forbidden City, were arranged for congress participants.

The IPC not only provides a forum to promote the exchange of new research findings, scientific ideas, and methodology, but also plays an important role in nurturing research collaborations, especially across interdisciplinary areas. The 20th century witnessed a tremendous accumulation of biological, taxonomical and biostratigraphical data in palaeontology and the close intercrossing of disciplines such as molecular and evolutionary biology, organic geochemistry, sedimentology, and tectonics. This demonstrates a strong vitality and remarkable progress in palaeontology. IPC2006 manifested such remarkable progress and highlights its continuation through to the 21 st century.

IPC2006 also provided a unique opportunity for Chinese palaeontologists to communicate with international colleagues and to discuss with them their recent research achievements. After several generations' endeavor, palaeontology has become one of the most flourishing and active disciplines in natural sciences in China. Particularly in recent years, Chinese palaeontologists have obtained a substantial number of research results across a variety of fields of palaeontology, including the origin of early life on earth, the Chengjiang biota and Cambrian explosion, the earliest chordate, the origin of birds and angiosperms, the mass extinction event of the PermianTriassic transition, and global chronostratigraphy. Chinese palaeontologists are becoming more active in international academic organizations. With many new findings reported in the recent years, China has become a focal point in global palaeontological circles. And international collaborative projects among palaeontologists are remarkably increasing.

There was extensive media coverage of the IPC2006 activities by the Xinhua News Agency, Guangming Daily, China Daily, Peoples' Daily, China News Agency, CCTV, Beijing TV, and Xinhua News Net. It is recognized that palaeontology has begun to demonstrate new vitality due to the intercross with other disciplines and the adoption of new methods. The IPC2006 theme "Ancient Life and Modern Approaches" suits such development.

During the congress, young palaeontologists and students from research institutes, universities and museums of different regions actively participated in the discussions and presented their research results. Many were also involved in activities associated with the organization of the congress.

National and international supports assured the successful running of the congress. Richard J. Aldridge, the former President of IPA from the University of Leicester (UK) sent letters to the organizers to congratulate them on the success of IPC2006 in Beijing. Aldrigde noted that he was grateful to "all the many members of the organizing committees and 
teams for arranging such an exceptionally successful meeting", "I can say without reservation that it was the most enjoyable and rewarding conference I have been to in my whole career", "you have surely shown that the IPC meetings are ones that no palaeontologist, whatever their specialism, can afford to miss". The new IPA President David Harper from the University of Copenhagen (Denmark) also expressed his congratulations and appreciations, noting that "The high standard of science presented was matched by the excellent organisation of both the scientific and social parts of the programme".

It is very gratifying to see that palaeontologists worldwide are able to show such great passion and commitment to our science and that a younger generation of researchers has emerged on the international platform suggesting a prosperous future for palaeontology.

\section{Acknowledgements}

The Organizing and Executive Committees of IPC2006 would like to thank all the sponsors who provided financial and professional support, including China Association for Science and Technology (CAST), Chinese Academy of Sciences (CAS), National Natural Science Foundation of China (NSFC), International Palaeontologiclal Association (IPA), International Union of Geological Sciences (IUGS) and Geological Society of China (GSC). We greatly appreciate the efforts of the co-organizers from China University of Geosciences (Wuhan and Beijing), State Key Laboratory of Palaeobiology and Stratigraphy (Nanjing, NIGPAS), Research Center of Palaeontology and Stratigraphy, Jilin University, China Geological Survey (CGS), Institute of Geology, Chinese Academy of Geological Sciences, Beijing Natural history Museum, China Museum of Geology, Northwest University (Xi'an) and China Dinosaur Park (Changzhou).

Special thanks are due to the University of Science and Technology of China Press for publishing the special volume of the congress abstracts over a very short time frame.

We also would like to express our thanks to the young staff, graduate students and volunteers from Peking University, Institute of Vertebrate Palaeontology and Palaeoanthropology, CAS, Nanjing Institute of Geology

\title{
The Second Annual Workshop on International Geological Map of Asia at 1:5000 000 Scale
}

\author{
Beijing, China, April 23-29, 2006
}

\section{Introduction}

The International Geological Map of Asia at 1:5 000000 Scale (IGMA 5000) is a major cooperative project under the aegis of the Commission for Geological Map of the World (CGMW). Launched in 2005 and expected to be completed in 2010 , the project is conducted by the Subcommission for South and East Asia in conjunction with the CGMW Subcommissions for Northern Eurasia, the Middle East and Seafloor Maps, and the geological surveys or institutions of Asian and related countries. Prof. J.P. Cadet, CGMW president, and Prof. Ren Jishun, CGMW vice-president from China Geological Survey (CGS), are coordinators of the project.

The IGMA 5000 covers the whole of Asia and its adjacent regions from the Aegean Sea in the west to the Mariana Trench in the east, and from the Arctic Ocean in the north to the Jawa Trench in the south. It comprises I, II, III, IV and V map sheets, taken charge of by the Northern Eurasia Working Group (coordinator: Dr. O.V. Petrov, CGMW vice-president from VSEGEI, Russia), the Middle East Working Group (coordinator: Dr. A. Haghipour, CGMW vice-president from Geological Survey of Iran), the China, Mongolia, Korea Peninsula and Mainland Southeast Asia Working Group (coordinator: Dr. Peng Qi- ming from China Geological Survey), the South Asia Working Group (coordinator: Mr. Ajit Kumar from Geological Survey of India) and the Japan and Maritime Southeast Asia Working Group (coordinator: Dr. Koji Wakita from Geological Survey of Japan), respectively. The final result will be a publication of the IGMA 5000 and its explanatory text. The former is to be available in two formats: a printed map at a 1:5 M scale and a digital map on CD-ROM with a spatial database, and the latter is to be published in the form of a book, whose planned title is Geological Evolution of Asia.

This is an arduous and challenging task, since the map that is under way is not only the first digital Asian geological map to be compiled jointly by geologists from about 20 countries, but also the first map to integrate onshore and offshore geology of Asia, with the great complexity of geology in the globe. The successful completion of the project will be a deep contribution to geosciences of the world. The IGMA 5000 will become the base for several specific thematic maps of Asia, such as tectonic map, metallogenic map, metamorphic map, map of fuel and energy resources, hydrogeological map, map of geological and environmental hazards, etc. Its achievements will greatly upgrade the research of the Asian geology. and Palaeontology, CAS, for providing excellent service in the preparation stages and duration of the congress.

\section{Qun Yang, Yongdong Wang, and Haifeng Wang \\ Executive Committee for the 2nd \\ International Palaeontological Congress \\ (IPC2006) \\ Nanjing Institute of Geology and \\ Palaeontology \\ Chinese Academy of Sciences \\ Nanjing 210008 \\ CHINA \\ qunyang@nigpas.ac.cn; \\ ydwang@nigpas.ac.cn; \\ hfwang@nigpas.ac.cn}

\section{Elizabeth A. Weldon \\ China University of Geosciences \\ Wuhan \\ CHINA and \\ Deakin University, Melbourne \\ AUSTRALIA \\ eaweldon@gmail.com}

Up to now, there have been more than 100 geologists involved in the project. They are from Cambodia, China, France, India, Indonesia, Iran, Japan, Kazakhstan, DPR of Korea, Republic of Korea, Malaysia, Mongolia, Myanmar, Russia, Thailand and Vietnam respectively.

The first annual workshop took place in Beijing, China from March 29 to April 3, 2005. More than 40 participants from 14 countries attended the meeting. The workshop focused on discussion about the draft plan for compiling the IGMA 5000, including geographic base frame and spatial database development, as well as organization and tentative schedule for the project.

\section{Second Workshop}

The second annual workshop on the IGMA 5000 was held on April 23-29, 2006 in the Tangshan Holiday Conference Center of Beijing, China, organized by the Institute of Geology, Chinese Academy of Geological Sciences (CAGS) and sponsored by the China Geological Survey and the CGMW Subcommissions concerned. Over 60 geoscientists from 16 countries participated in it (photo). The meeting consisted of 3 components: 1) academic exchange: oral presentations on the regional geology of Asia, mainly on stratigraphic classification and correlation, and tectonomagmatic events; 2) key subjects: on the legend for IGMA 5000, geographic base map, and GIS and database; and 3) post-workshop field trip to Yunmeng Hill in Beijing: to visit the Mesozoic metamorphic core complex that was recognized earliest and studied deeply in China.

Altogether, 21 invited lectures on the Asian geology were delivered at the first two-and-a half day workshop, having 30-35 minute timeslots. Most of them had been 


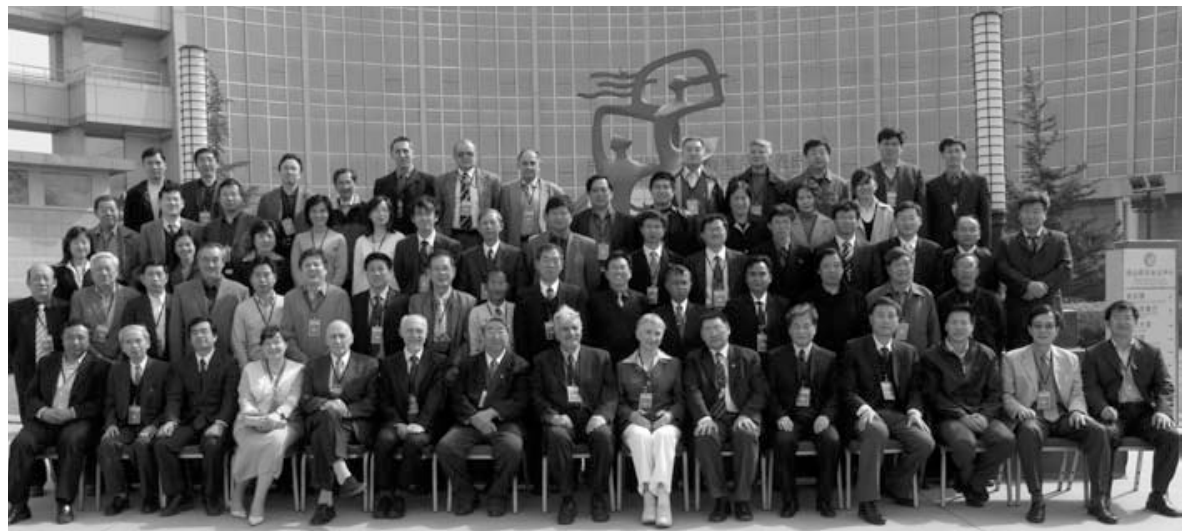

Participants and organizers of the second workshop.

included in the Proceedings of the Second Workshop on IGMA 5000, Volume I. They are:

- Tatiana Koren: Stratigraphy Standards of Subdivision and Correlation of the Phanerozoic Sections in the Russian Part of Asia,

- Igor Pospelov: Permian Correlation for the Central Asia and Triassic Correlation for Siberia,

- Oleg Fedorenko: 1:5M Kazakhstan Part of Geological Map,

- Onongyn Tomurtogoo: Geology of Mongolia-An Overview,

- Abdolazim Haghipour: Geology and Structural Units of the Middle East

- Liudong Ren: Geochronological Framework of the Early Precambrian in the North China Craton,

- Huaikun Li: Mesoproterozoic-Neoproterozoic Stratigraphy Subdivision and Major Thermotectonic Events in China,

- Xiaochi Jin: Outline of Devonian to Triassic Successions of Some Continental Blocks in South and Southwest China,

- Xueyi Xu: Nature of the Mantle Source of the Tianshan Carboniferous Rift-related Basalts,

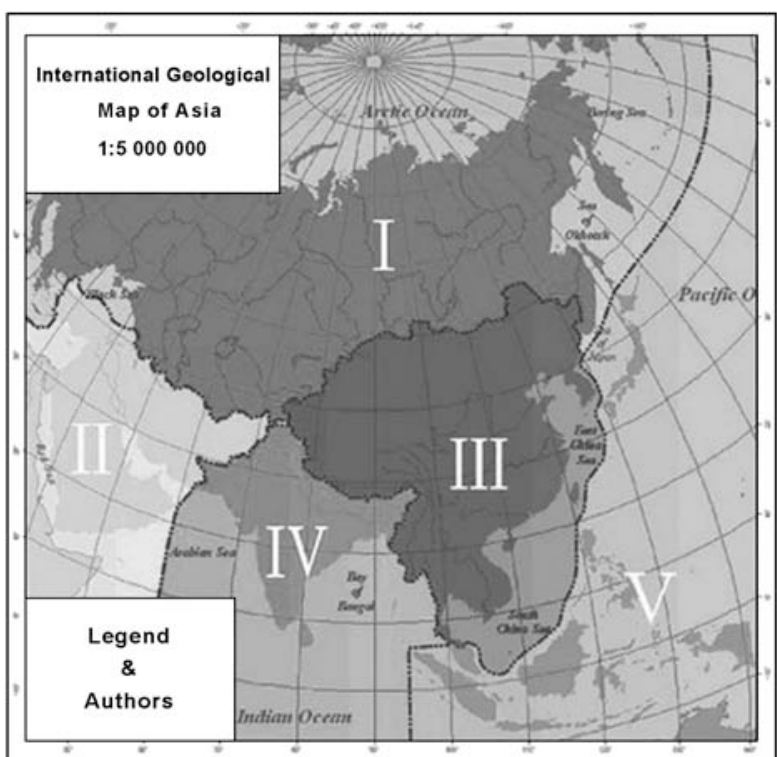

The scope of IGMA 5000.
- Jianren Mao: The Mesozoic Tectonomagmatic-Mineralizing Events in Southeastern China and Pilot Study of Comparison with Japan,

- Dawei Hong: An Outline about Spatial and Temporal Distribution of the Granitoids in China,

- Tao Wang: Timing of Intrusions and Constraint on Tectonic Evolution: Two Case Studies from the Altai Orogen and North Qinling Orogen, China,

- Guoqing Zhou: Ophiolites and Blueschists in China: Their Temporal and Spatial Distribution and Compositional Evolution,

- Ajit Kumar: Salient Tectonomagmatic Events and Stratigraphic Correlation of India and Its Environs,

- U Soe Thi Ha: Stratigraphy of Myanmar,

- Pol Chaodumrong: Stratigraphy and Tec-

- Tran Van Tri: Tectonosedimentary and Tectonomagmatism Stages of Indochina Peninsula,

- Sieng Sotham: Geology of Cambodia,

- Bok Chul Kim: A Brief Review on the Tectonostratigraphy and Magmatism of South Korea,

- Koji Wakita: Geology of Region V for IGMA 5000 International Geological Map of Asia: Working Group V Land Area.

The April 25-27 sessions were devoted to discussion and examination of 3 keynote reports: "Explanation for compiling the geographic base map of IGMA 5000", presented by Prof. Benxian Fan; "Preliminary legend for land and offshore areas of IGMA 5000", submitted by Prof. Jishun Ren and Dr. Koji Wakita respectively; and "GIS and database development in compiling IGMA 5000", given by Dr. Jun Wang et al. The discussions were very fruitful. The participants unanimously agreed upon the general legend for the IGMA tonics of Thailand,

- Shinji Takarada: 1:5 M
5000, and several suggestions and ideas were put forward to make it perfect. For example, some legends for special features of the oceanic areas need to be implemented. As for the geographic base, the participants agreed not to show national boundaries on the printed map and in database, and stressed that special attention must be paid to crossboundary geographic names, namely, only those names which have been acknowledged by all the countries concerned can be adopted. Besides, they recommended that DEM from ETOPO2 instead of bathymetry contours should be used for the background of offshore geology.

The work carried out by Dr. Jun Wang and his colleagues to build the database of the IGMA 5000 was appreciated by the attendees, namely, the quality and high level of documentation of the flow chart. However, the databank might be too detailed for the compilation of the IGMA at a $1: 5 \mathrm{M}$ scale, and improvement is going to be made. They recommended fitting the level of information of the database with the scope of the IGMA 5000 legend, and proposed that Working Group III experiment this newlyadapted version of the database, while compiling the Chinese part of the IGMA 5000. This pilot project should be presented and discussed at the third workshop.

The workshop ended by sightseeing around the city of Beijing on April 29. It was a great success, as said in the minutes of this workshop written by CGMW secretary general Dr. Philippe Rossi: "The participants underline the high quality of the preparation of the second workshop, and are confident that the coordinator and his team and six working groups will successfully complete the IGMA 5000 project on the scheduled time". Prof. Tatiana Koren commented favorably: "The workshop was very productive and successful". And Dr. Shinji Takarada said with great confidence: "It was a very good meeting in Beijing. Let's make a good new generation map".

The next workshop is to be held in September 2007. A more encouraging meeting will be waiting for all participants.

\section{Jishun Ren and Liwei Xiao}

Institute of Geology

Chinese Academy of Geological Sciences

26 Baiwanzhuang Road

Beijing 100037

CHINA 


\title{
Origin of the Caribbean Plate Conference
}

\author{
Siguenza, Spain, May 29-June 2, 2006
}

An international research conference, entitled "Geology of the area between North and South America, with focus on the origin of the Caribbean Plate", took place in Siguenza, Spain, from May 29-June 2, 2006. Fifty five people from 11 countries attended the meeting, which was chaired by Drs. Albert W. Bally, Maria Antonieta Lorente and David G. Roberts. Siguenza authorities and volunteers lent a great deal of enthusiastic support, while BP, Repsol, Shell, Statoil and SEPM provided financial encouragement.

Siguenza is a beautiful mediaeval town whose old centre includes fine stone architecture and a superb cathedral. Steep cobbled streets ascend to a majestic, renovated 12th century castle, today a luxurious hotel where our meeting took place.

The castle granted use of a splendid, arched stone meeting room and offered accommodation in atmospheric surroundings $-\mathrm{a}$ baronial dining hall and rooms furnished with antiques, ranged around a central courtyard.

We chose Siguenza for the meeting because it is easily accessible by road or rail from Madrid or Barajas airport. It offers conference facilities, cultural interest, restaurants and bars and is sited in countryside with castles and ancient villages among spectacular rock outcrops, visited in a mid-week field

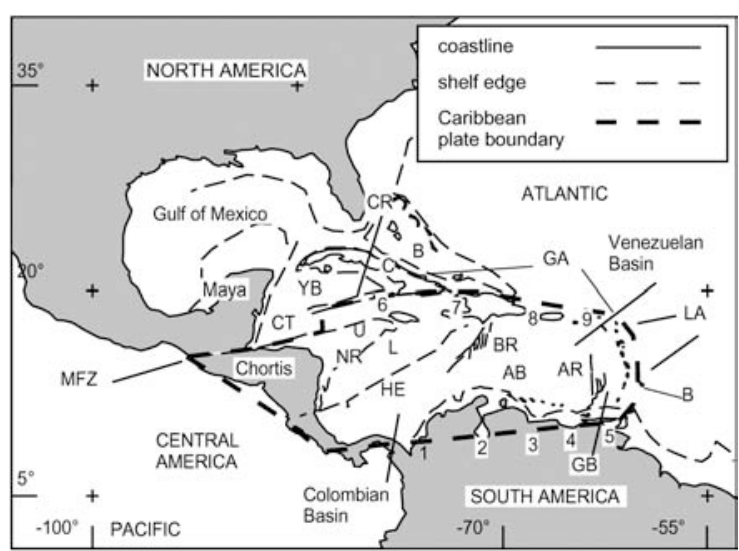

Middle America, geographic elements referred to in text, $A B-$ Aruba-Blanquilla, AR-Aves Ridge, B-Bahamas, BR-Beata Ridge, C-Cuba, CR-Cayman Ridge, CT-Cayman Trough, GA-Greater Antilles, GBGrenada Basin, HE-Hess Escarpment, LA-Lesser Antilles, NR-Nicaragua Rise (Upper, Lower), YB-Yucat'n Basin. Numbers indicate pull-apart depressions along the southern and northern boundaries of the Caribbean Plate (1-Lower Magdalena, 2-Maracaibo, 3-Guarumen, 4-El Hatillo, 5-Gulf of Paria, 6-east Cayman Trough, 7-North Haiti, 8-Mona Passage, 9-Anegada Passage). trip. Importantly, its small size, and location of conference attendees in the same hotel assured that people stayed more or less together and encouraged

Over 40 scientific papers and posters were presented and discussed (abstracts at www.kjgeology.com). Speakers had ample time ( 35 minutes) rush and nobody went to sleep. Fifteen question and answer followed each talk and round table discusend of each day provided opportunity for further discussion. sented to the meeting each morning. the was a sesion at the new data, beyond that sum(James, 2006a,b and Pindell, et conference format and success prompts us to plan Siguenza II for

Perhaps the greatest obstacle to Caribbean understanding is the absence of ocean fracture patterns, magnetic anomalies and recognized preading ridges (except for the centre
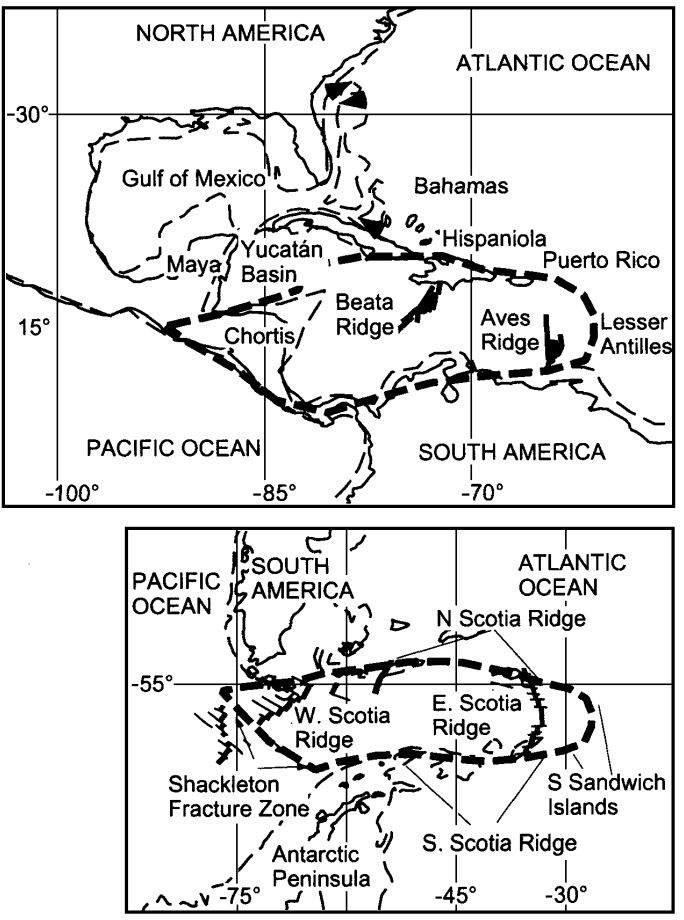

The Caribbean and Scotia Plates (outlined in heavy dashed lines) are strikingly similar in size and shape. Both lie between large continental masses. Scotia is known to have formed in place. The plates are bordered to the east by active volcanic arcs (Leser Antilles, South Sandwich Islands). The Shackleton Fracture zone parallels Central America. Analogy between the plates suggests that the Beata and Aves Ridges were spreading centres, equivalent to the West and East Scotia Ridges, and that continental fragments are dispersed along the eastern Greater Antilles, as along the North Scotia Ridge. of the Cayman Trough).

Basaltic eruptions have thickened large areas of the Caribbean Plate and obscure its deeper architecture. Where this has not occurred, the crust is thinned by extension and shows wedges of dipping flows characteristic of the change from rifting to spreading. Nowhere has the original crust been sampled in place, but regional geological considerations (rifts in North and South America and obducted rocks on Cuba, Hispaniola, Puerto Rico, La Desirade, Costa Rica) suggest its Jurassic age. Liassic-Lower Dogger volcaniclastic rocks in Costa Rica, upper Jurassic volcanic rocks on Cuba, Hispaniola, Puerto Rico and La Desirade and volcaniclastic rocks at least as old as Albian in the northeastern Lesser Antilles suggest that subduction began along with spreading.

There are two end-member models for the origin of the Caribbean Plate and both were discussed at this meeting, with the champions of each model sitting at the same conference table.

The established idea is that the Caribbean Plate formed in the Pacific during the Jurassic and thickened in the Cretaceous above a mantle plume or a hotspot (Pindell and Barrett, 1990). While migrating eastwards the resulting plateau collided with a volcanic arc at the eastern, subducting margin of the plate, causing subduction to stop and reverse its polarity. The plate then entered the space between North and South America, colliding with the Yucatan Peninsula and Colombia on entry and picking up activity ceased when the arc collided obliquely and diachronously with the Florida-Bahamas platform and along northern South America in the Eocene to Oligocene. The continental fragments of Yucatan and Colombia resurfaced after deep burial (ca. $75 \mathrm{~km}$ ) and $\mathrm{Hp} / \mathrm{Lt}$ metamorphism. Cuba and the Yucatan Basin became detached from the Caribbean Plate and joined North America. The remaining plate continued its eastward progress, interacting diachronously with northern South America pieces of those continental areas. Volcanic 


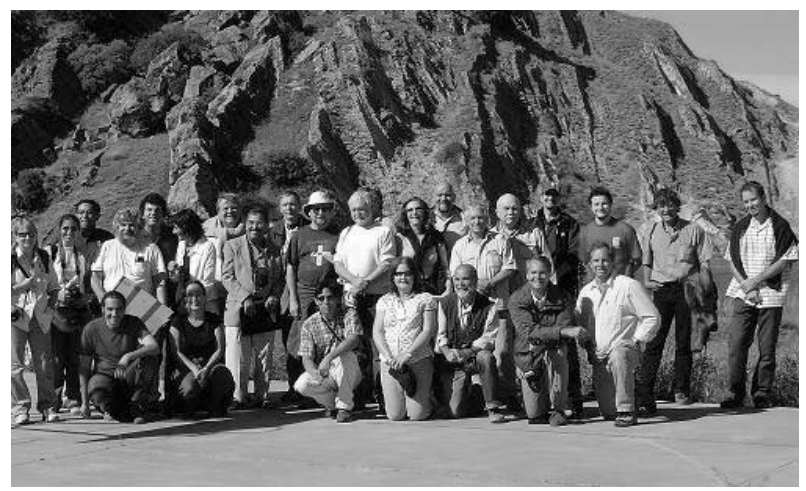

Field excursion to Triassic outcrops near Siguenza.

to create northern uplifts and complementary foreland basins and causing fragmentation and dispersal along the Greater Antilles. Inter- or back-arc spreading in the Grenada Basin separated the Aves Ridge from the Lesser Antilles, which are the active remains of the arc that entered the Caribbean. This model invokes major (up to 80 degrees) rotation of the large continental blocks of Yucatan (from the Gulf of Mexico) and Chortis (from SW Mexico) and accretion of the latter to the northwestern part of the Caribbean Plate. It geometrically requires complex processes, such as slab roll-back in different directions below the entering plate and in the opening Yucatán Basin, for which there are no supporting data.

The alternative understanding is that the Caribbean Plate formed between North and South America (e.g., James, 2005). Oceanic spreading following Triassic-Jurassic rifting of Pangea and drift of North America to the north west in the late Jurassic-Cretaceous created a growing plate with continental fragments distributed around its margins (a new understanding that sees at least a third of the plate as continental). Jurassic rifts on Yucatan and Chortis parallel each other and rifts in $\mathrm{N}$ and $\mathrm{S}$ America, showing that these blocks have not rotated. The rifts and the faulted eastern margins of the blocks allow a simple palaeogeographic reconstruction after restored sinistral movement equal to early (Jurassic-early Cretaceous) offset along the Cayman Trough. The Caribbean plate exhibits the same NE fabric, which argues

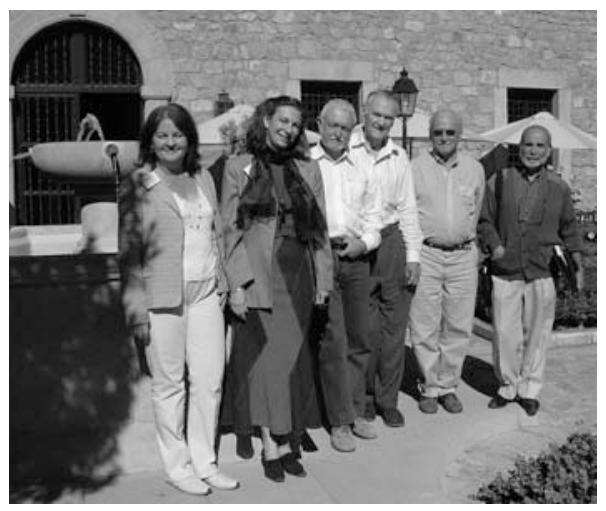

Conference organizers and chairpersons, courtyard of Siguenza castle. against the (radial) plume model for plateau thickening. Instead, the pattern reflects the orientation of listric extensional faults, seen on seismic, related to plate thinning. Extension occurred along with continued separation of $\mathrm{N}$ America from $\mathrm{S}$ America, recorded by diverging fracture patterns in the Atlantic east of the Lesser Antilles. It resulted in decompression melting and plateau thickening that occurred in pulses at around 120,90 and $76 \mathrm{Ma}$. They were accompanied by pauses and reorientation of volcanic arc activity, with changes in chemistry from primitive to calc-alkaline and tonalitic intrusion indicating continental input. Associated unconformities separating metamorphosed oceanic/arc rocks from overlying shallow marine limestones testify to significant convergence and uplift resulting from plate expansion. The process explains $\mathrm{Hp} / \mathrm{Lt}$ metamorphism in a simpler alternative to deep burial followed by exhumation. Episodes of enhanced organic productivity/preservation seem to correspond with these events.

In the absence of in-place oceanic data, the in-place model turns to global analogues. The Caribbean, Scotia and Banda plates are strikingly similar in shape and dimension and share a common tectonic setting). Each lies between sinistrally offset major continental blocks to the north and south. Divergent spreading patterns in oceanic areas both east and west of the plates show their extensional settings. Each plate has a curved volcanic arc in the east and Banda and the Caribbean are bounded by northwest trending volcanic arcs in the west. Scotia and Banda both carry spreading ridges and dated magnetic anomalies and both are known to have formed in place. The similarities imply that the Caribbean Plate formed in place also, by mid ocean spreading (Beata Ridge) followed by east-west back-arc spreading (Aves Ridge). It also suggests that the plate is rimmed by continental fragments and these are evidenced by continental rocks on Cuba, northern Hispaniola and Puerto Rico, crustal thicknesses, gravity data, ancient zircons in arc rocks and abundant high silica rocks such as tonalites and andesites. Such data indicate continental basement beneath the whole of Central America, which has always formed the western margin of the Caribbean Plate.

The Geological Society of London will present the conference proceedings in a Special Publication. The volume will be unusual in that two of the editors, Keith James and Jim Pindell, champions of the different Caribbean models, will collaborate to present and discuss their different ideas. Maria Antonieta Lorente will be an impartial third editor. More than thirty articles will present new data. Points arising from conference discussion will appear at the end of the book, along with comments from the conference chairs and with studies and ocean drill sites suggested to resolve the debate.

\section{References}

James, K. H., 2005, A simple synthesis of Caribbean geology: Transactions, 16th Caribbean Geological Conference, Barbados, Caribbean J. of Earth Sciences, v. 39, p. 71-84. James, K. H., 2006a Arguments for and against the Pacific origin of the Caribbean Plate: discussion, finding for an inter-American origin: Geologica Acta, v. 4, no. 1-2, p. 279-302.

James, K. H., 2006b, Structural Geology: from local elements to regional synthesis: In: Bundschuh, J. and G. E. Alvarado (eds.) Central America: Geology, Resources and Hazards, Ed. Balkema, Chapter 11, p. 277-321.

Pindell, J. L., and S. F. Barrett, 1990, Geological evolution of the Caribbean region; A plate-tectonic perspective, in, Dengo, G. and J. E. Case, The Caribbean Region, The Geology of North America, vol. H, Geological Society of America, p. 405-432.

Pindell, J., L. Kennan, K-P Stanek, W. V. Maresch and G. Draper, 2006, Foundations of Gulf of Mexico and Caribbean evolution: eight controveries resolved: Geologica Acta, v. 4, no. 1-2, p. 303-341.

\section{Keith H. James}

Honorary Departmental Fellow

Institute of Geography and Earth Sciences University of Wales

Aberystwyth

$U K$

khj@aber.ac.uk

\section{Maria Antonieta Lorente}

Stratigraphy Professor

Postgraduate Program

Universidad Central de Venezuela

Caracas

Venezuela

lorentema@yahoo.es 


\section{InterRad 11 and Triassic Stratigraphy Symposium}

\author{
- A joint conference hosted by the International Association of \\ Radiolarian Paleontologists, IGCP 467, and the Subcommission \\ on Triassic Stratigraphy
}

Wellington, New Zealand, March 19-24, 2006

The first international radiolarian conference held in the Southern Hemisphere attracted record numbers of radiolarian researchers to Wellington, New Zealand, from March 19 to 24,2006 . The conference was held in conjunction with a meeting of IGCP Project 467, Triassic time and trans-Panthalassan correlations. The 120 participants came from 19 countries, with 35 participants from Japan alone, and 32 students. Particularly pleasing was the large number of participants from eastern Europe, including eight from Russia. The 72 oral presentations included 17 plenary talks, nine of these open to public, which addressed the key themes of the conference: Triassic catastrophes and their consequences, biological indicators of oceanographic change, micropaleontological methodologies for the 21 st century, and radiolarian solutions to tectonic problems.

A highlight for radiolarian researchers was the presence of two visionaries in radiolarian research: William R. Riedel, who revolutionised Cretaceous-Cenozoic radiolarian biostratigraphy through studies of cores collected in the course of the Deep Sea Drilling Project, and Emile A. Pessagno, who revolutionised Mesozoic radiolarian biostratigraphy through perfection of the hydrofluoric acid rock-leaching method to retrieve radiolarians from indurated rocks and use of the scanning electron microscope for refined taxonomic discrimination.

In addition to the oral papers, 32 posters were presented. Student prizes were awarded

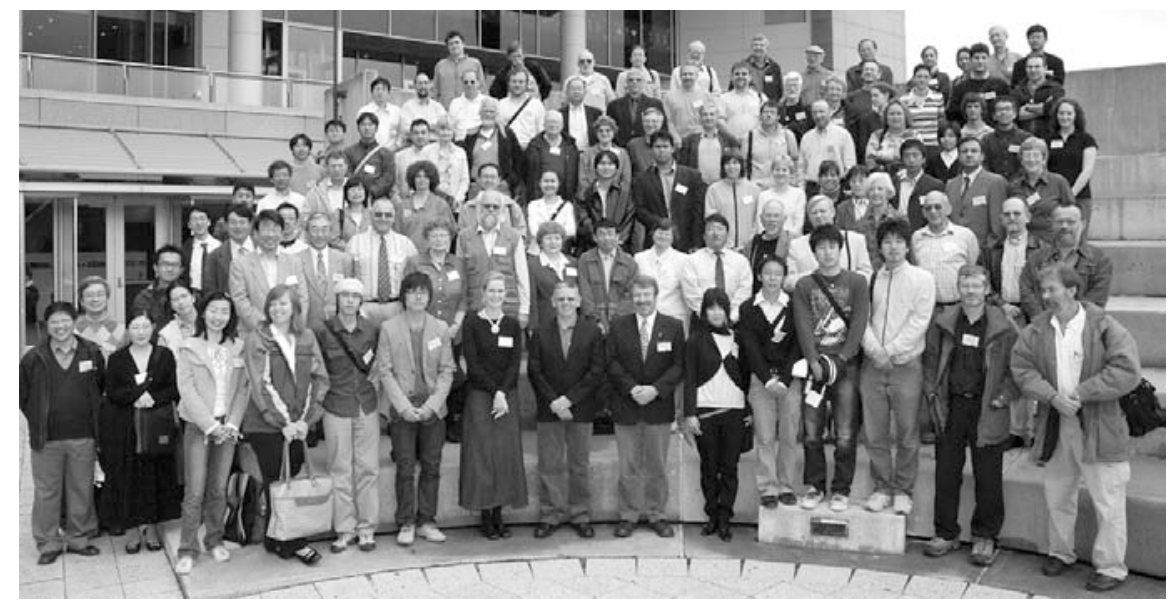

Most of conference participants, March 20. Photo K. Whitley, GNS. ers are far from being resolved. In a plenary session, Dr Ian Metcalfe reviewed the available evidence for discriminating between competing causes of the Permian-Triassic boundary crisis and in so doing explained the basis for the currently accepted age for the base of the Triassic (252.6 Ma). His thesis was supported by Dr Heinz Kozur, advocating very persuasively for a direct link with LIP volcanism and eruption of the Siberian Traps. Dr Martial Caridroit (and Patrick de Wever subsequently in the Biosilica symposium) provided a philosophical consideration of the fossil record and the much-vaunted magnitude of the extinction event at the end of the Permian. Their view was that the extinction rate may have been vastly over exaggerated.

New Zealand contributors Hamish Tomoko Yuasa of Tokyo Gakugei University won the best oral paper award for "Phaeodarians found a home? Molecular phylogenetic study of Phaeodarea". Two posters tied for best poster and so the award was shared between Susumi Shibutani, Ehime University, and Seiji Tanaka, Kyushu University, for their posters on "Radiolarian assemblages and chemical compositions of lowest Jurassic (Hettangian/Sinemurian) black chert sequence from the Ikuno District, Tamba Terrane, Southwest Japan" and "Radiolarian distribution using vertical multiple plankton sampler and paleoceanography in the Bering Sea", respectively. It was very pleasing to see the wide-ranging multidisciplinary research that is being undertaken by these young researchers.

\section{Conference symposia}

The conference comprised three symposia: Triassic stratigraphy, Nigrini, and Biosilica. In the Triassic Symposium Dr Mike Orchard, Convenor of IGCP 467 and Chair of the Subcommission on Triassic Stratigraphy, drew attention to the deadline that IUG have set for determining appropriate GSSPs for all stage boundaries. This impacts on the Triassic Period in particular because as yet only two stage boundaries have been fixed: the base Induan (Permian-Triassic boundary) and the base Ladinian. Formal proposals for several others are almost ready for voting by members of the subcommission, but oth-

Campbell, Ian Raine, Jack Grant-Mackie and Bruce Waterhouse drew attention to the status of New Zealand Triassic studies and especially the woeful lack of current research on aspects of paleontology and chronostratigraphy. Yet it was widely recognised during the conference that little-deformed and metamorphised tuff-rich fossiliferous New Zealand Murihiku Supergroup sequences (Murihiku terrane) offer tremendous potential for establishing age control for much of Triassic time. Clearly this is a project waiting to happen. Many Triassic workers, and radiolarian workers alike, were attracted to the conference because of the opportunity to visit the Permian-Triassic boundary section at Arrow Rocks in Whangaroa Bay, Northland. Those who made it on Trip 1 were not disappointed! This is undoubtedly the most significant deep marine Permian-Triassic record for the Panthalassa Ocean in the Southern Hemisphere. A GNS Monograph presenting all available data will be published within the next three months.

The Nigrini Symposium on biological indicators of oceanographic change honoured our colleague Cathy Nigrini, who passed away in January 2005, and acknowledged her major contributions to Cenozoic radiolarian taxonomy, biostratigraphy and paleoceanography. The symposium began with plenaries by local researchers Helen Neil, Scott Nodder and Chris Hollis, who outlined the oceanographic regime around New Zealand and showed how studies of plankton (including radiolarians) in sediment traps, surface sediments and sediment cores were advancing understanding of the influence that climate change has had on ocean productivity offshore eastern New Zealand. The following papers spanned the full breadth of current radiolarian research from studies of living radiolaria to detailed coreand outcrop-based studies of faunal changes during episodes of significant climatic or environmental change. Atsushi Matsuoka spanned this range in a single talk, demonstrating how his laboratory studies of living radiolarian feeding strategies help to explain survivorship patterns across mass extinction horizons. The symposium finished with three 


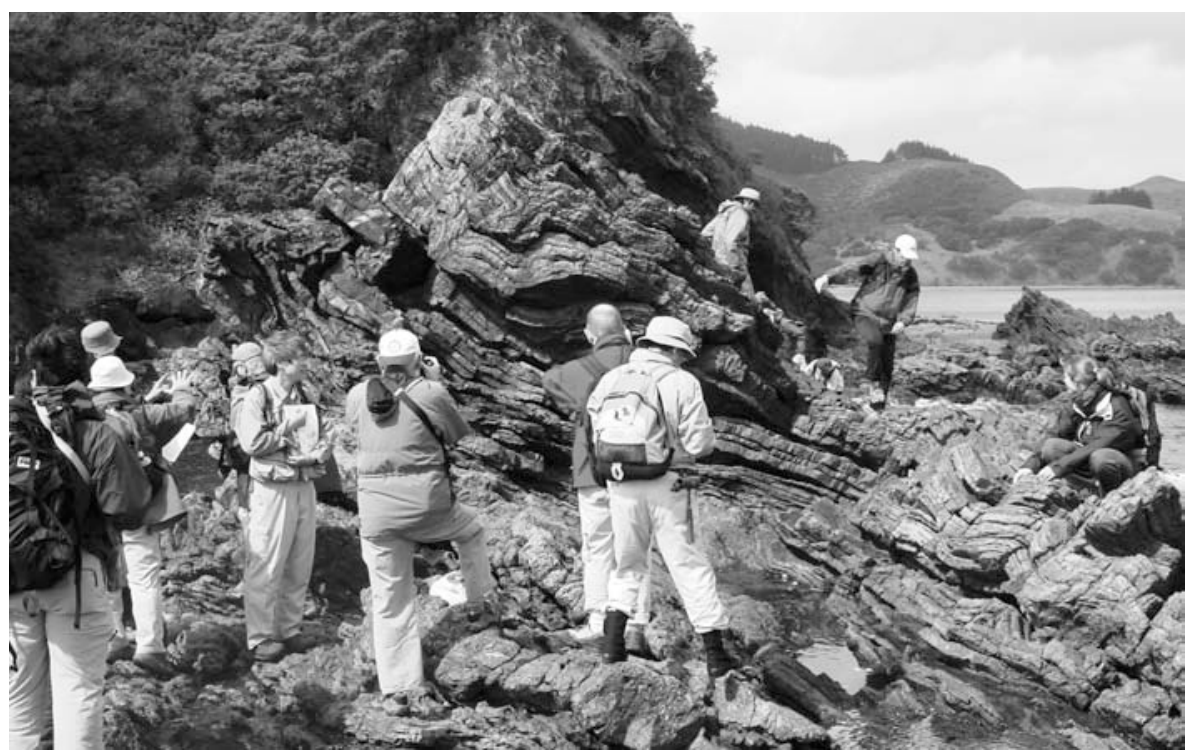

Field trip participants view the Permian-Triassic boundary succession at Arrow Rocks, Oruatemanu Island, Northland. Photo C. Hollis, GNS.

public plenary talks: a retrospective on deep sea drilling from William Riedel, an introduction into the new phase of ocean drilling within the framework of the Integrated Ocean Drilling Program from Kozo Takahashi, and an overview of the contribution that radiolarian research has made to understanding the evolution of the Cenozoic ocean from David Lazarus.

The Biosilica Symposium included oral papers on a wide range of themes, including biodiversity, taxonomic databases, phylogenetics and evolution, tectonics, petroleum exploration and biostratigraphy. Plenary talks by Patrick De Wever and James Crampton emphasised the serious problem of sampling bias in traditional paleo-diversity studies. However, they also pointed to solutions that will give new rigour to fossil-based studies of biodiversity and stratigraphy. That part of the solution comes as international database initiatives that will help paleontologists speak the same taxonomic language was highlighted in a series of talks on database projects: Paleobiology Database (David Lazarus), WoRaDD (Demetrio Boltovskoy), RadWorld (Jean-Pierre Caulet), Radiolarian Information System (Yuri Agarkov). This theme was continued in a databases workshop where participants recognised the urgent need to coordinate these initiatives to avoid duplication and establish systems that can eventually be integrated. Another initiative to be applauded is the Joint Haeckel and Ehrenberg Project, a Japanese-led project to re-examine and re-describe type material held in collections in London, Berlin and Jena. As explained by Noritoshi Suzuki, this work has the potential to resolve a problem that has thwarted radiolarian research for generations: the lack of well-defined or definitive holotypes for many common radiolarian species and genera. In the public plenary talks for the Biosilica Symposium Sergey Zyabrev, Jonathan Aitchison and
Emile Pessagno gave a stimulating series of talks on the theme "Radiolarian solutions to tectonic problems" with spectacularly illustrated examples from the Russian Fareast, Tibet and Mexico.

\section{Conference excursions}

The conference included six field trips that covered almost every corner of New Zealand: from the Permian-Triassic boundary of Northland to the radiolarian-rich Cretaceous-Tertiary and Paleocene-Eocene boundary sections of Marlborough, and the New Zealand Triassic stage stratotypes of Southland. Combining geology with other aspects of New Zealand natural history and culture proved to be very popular with participants-most of whom were making their first visit to New Zealand. The main preconference excursion in Northland was led by Bernhard Spörli, Chris Hollis, Atsushi Takemura and Yoshiaki Aita. It focussed on the Permian-Triassic boundary sequence within Waipapa terrane and radiolarian-rich Paleogene limestone within the Northland Allochthon but included an introduction to New Zealand's giant araucarian, the kauri tree, and the industries that exploited the kauri forests.

Follow-on pre-conference trips delivered participants to the conference venue in Wellington by two routes. One excursion led by Chris Hollis and Murray Baker visited the geothermal fields and calc-alkaline volcanoes of the central North Island. The other excursion, led by Jack Grant-Mackie, Hamish Campbell and Rie Hori, visited key Triassic-Early Jurassic sections in Murihiku terrane on the North Island's west coast. A mid-conference excursion, led by Hamish Campbell, Bernhard Spörli and John Simes, to examine Triassic rocks of Torlesse composite terrane exposed on Wellington's south coast was a terrific introduction to local wetweather field conditions. The terrible weather did not faze the 77 participants. One hardy soul even went for an intentional swim.

The post-conference excursion to Southland, led by Hamish Campbell, escaped the wet weather and participants enjoyed five sunshine-packed days viewing the key stratotype sections for six of the eight local Triassic stages. Participants on the other post-conference excursion to Marlborough and North Canterbury, led by Chris Hollis, Percy Strong and John Bradshaw, were less fortunate with the weather but had the compensation of spectacular geology, fine food and comfortable accommodation. The excursion visited four K/T boundary sections in Marlborough: Woodside Creek, Mead Stream, Chancet Rocks and Flaxbourne River. As well as being one of the first three sections shown to contain an iridium anomaly in the $\mathrm{K} / \mathrm{T}$ boundary clay, the Woodside Creek section has a rich radiolarian record that shows almost $100 \%$ survival across the $\mathrm{K} / \mathrm{T}$ boundary as well as progressive first appearances of important Cenozoic taxathese events forming the basis of an early Paleocene radiolarian zonation.

The conference was hosted by InterRad, the International Association of Radiolarian Paleontologists, IGCP 467, the Subcommission on Triassic Stratigraphy and GNS Science. It was sponsored by the Royal Society of New Zealand and the New Zealand Government through the International Conference Fund, NIWA, Te Papa Tongarewa Museum of New Zealand, Wellington City Council, Zeiss Australasia, Webster Drilling and Clevedon Coast Oysters. The conference abstract volume can be downloaded from the GNS website: www.gns.cri.nz/interrad.

The next InterRad conference will be held in Nanjing in September 2009. The next sponsored meeting of STS/IGCP 467 was held in Svalbard, Norway during August 2006, with a final meeting scheduled for Albuquerque, New Mexico in May 2007.

Chris Hollis \& Hamish Campbell

GNS Science

PO Box 30-368, Lower Hutt

NEW ZEALAND 


\section{The International Conference on "Geoheritage for Sustainable Development"}

\author{
Druskininkai, Lithuania, May 27-30, 2006
}

This conference, in the spar town of Druskininkai in southern Lithuania (May 27-30, 2006), was held under the auspices of ProGEO (European Association for the Conservation of Geological Heritage) Northern European Working Group, IUGS Commission GEM (Geosciences for environmental management) working group IBC (International borders-Geoenvironmental concerns), Lithuanian Geological Survey, Polish Geological Institute, and the Institute of Geology and Geography, Lithuania. It was held under the auspices of INTERREG project 2005/041 (Elaboration of geoenvironmental assumptions for 'Geopark Yotwings' in the cross-border Polish-Lithuanian area) and IUGS-ICSU project Application of geoscience for sustainable development of cross-border areas. The aims of the conference were: to promote better understanding of geological heritage in Northern Europe and to aim at an increasing level of awareness concerning geological knowledge and related problems in society; to promote best practice on such matters as inventory, on-site management, planning, development of geotourism etc.; to strengthen trans-boundary co-operation and promote initiatives in application of elements of the geological heritage in sustainable development. Over 45 people attended the conference from seven European countries.

The first session was on 'Geodiversity and geological heritage of Northern Europe - from local to international significance'. The introductory lecture on 'Geoconservation in a multidisciplinary setting' by Lars Erikstad, Norway, set the scene by outlining difficulties that could be encountered in establishing traditional projects in some European countries. Erikstad went on to dis- cuss the possibilities of achieving more positive action by linking geodiversity with biodiversity, geoconservation with cultural heritage and by having more integration of geoheritage within landscape planning and tourism. Any, or all, of these of course involve broad co-operation where ProGEO could act as an important partner. This was followed by talks outlining geoconservation activity in a number of European countries where such co-operation is achieving results.

Olli Breilin, Jukka Ojalainen \& Susanna Ollqvist (Finland) [The Kvarken Archipelago in Western Finland-worthy of world heritage status] outlined the sequence of the archipelago's Quaternary geology, its deglacial history and the glaciated land uplift. The presentation displayed Finland's efforts to make an application to UNESCO's World Heritage committee to nominate the Archipelago as a world heritage site. The Kvarken archipelago has since been added to the UNESCO's list (July 2006).

Olli Breilin, Pertti Itkonen, Johansson Peter \& Susanna Olqvist (Finland) [Geotourism in Finland's National Parks-cooperation between Metsähallitus and the Geological Survey of Finland] also talked on geotourism in Finland and explored how geological outdoor maps present geological places of interest with easy accessibility for travellers and hikers. This is all part of a project to promote geotourism in national parks. Peter Johansson (Finland) [Nature tourism and geological heritage in central Finnish Lapland] followed this theme with outlines of plans to develop the Pyhä-Luosto National Park in Finnish Lapland more and more into a geological national park. Barry Thomas (UK) [ The work of the British Institute for Geological Conservation] outlined the work of the Institute stressing the work to establish a South Wales Coalfield Geopark in collaboration with the Countryside Council for , Wales and the National Museum of Wales.

Three papers outlined work in Lithuania, centered on geoheritage and geoconservation: Jurga Lazauskiene (Lithuania) [Geological setting of Druskininkai geoheritage], and Jonas Satkunas (Lithuania) [Geological heritage-protection by understanding of value], and Grazina Skridlaite, Rimante Guobyte, Migle Stancikaite, Daiva Norkunienė \& Alfonsas Gegznas (Lithuania) [Geological investigations for better understanding of protected area: Sartai Lake case (Northern Lithuania).

There were other papers outlining geoheritage and geoconservation in the Baltic region: Marek Graniczny, Halina Urban, Jonas Satkunas (Poland and Lithuania) [Geological investigations of the Polish and Lithuanian lands, since XVIII century to the present-common heritage], Dace Ozola (Latvia) [Protection and management of geological heritage in Latvia], Krista Täht (Estonia) [Island Saaremaa (Estonia) - worthy candidate of the UNESCO list of geoparks], and Szymon Uscinowicz, Grażyna MiotkSzpiganowicz \& Wojciech Jeglińki (Poland) [Coastal geotopes of Gdańsk]. There were two other papers in this session that stressed the need to understand how soils can have a bearing on geoheritage. These were Hanneke van den Ancker (The Netherlands) [Soils and soil systems related to geoheritage and geodiversity] and Enno Bregman \& Peter Dirk Jungerius (The Netherlands) [The "essen" of Drenthe. Threats to geoheritage sites in sustainable use as Plaggen soils in the Netherlands].

The second session was on the "Geological heritage and sustainable development in cross-border context'. This centred on the Lithuanian/Polish border area; the Suwalki/Suvalkija and Dzūkija region known for its exceptional beauty and its wilderness; a landscape resulting from its geological structure, tectonics, the palaeorelief of the basement, the influence of ice sheets in scouring and then depositing boulder clay and the subsequent erosional and

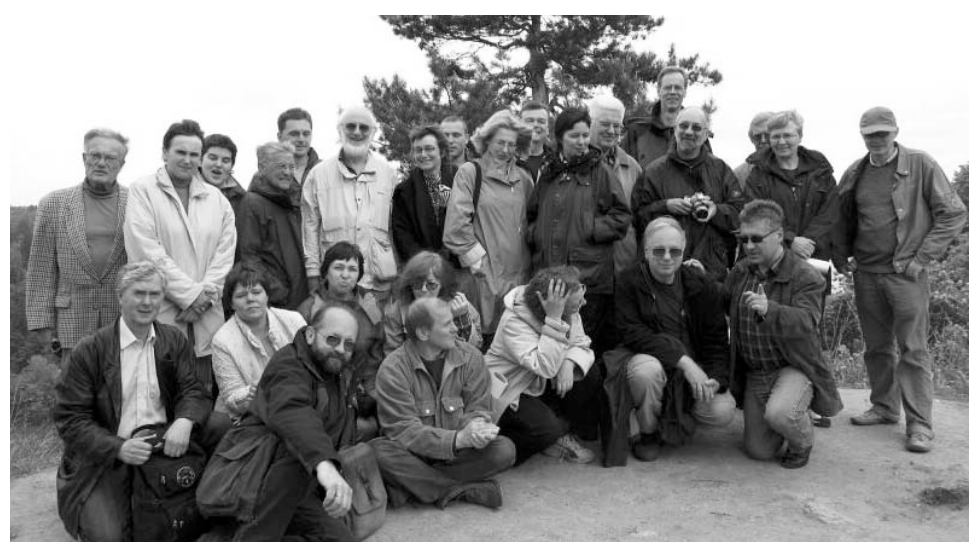

Participants of the conference during the field trip in the Suwalki Landscape Park in Lithuania.

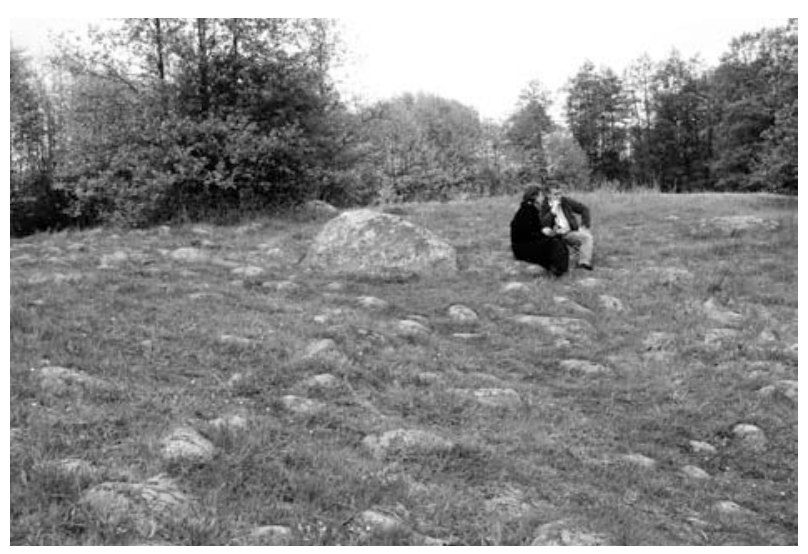

The Bachanowo boulder field in Poland. 
depositional action of the melt-waters. The scene was set by Jurga Lazauskiene, Marek Graniczny \& Jonas Satkunas (Lithuania and Poland) [Geoheritage and international borders] in exploring how cross-border mapping, monitoring, projects and other issues demonstrate the crucial value of geoscientific data in the sustainable development of the geo-environment in cross-border regions. Other papers were by Jonas Satkunas, Marek Graniczny \& Magdalena Czarnogorska (Lithuania \& Poland) [Selected examples of cross-border geological and geoenvironmental studies-Belt of Yotvings] \& [ Geodiversity of Polish-Lithuanian cross-border areaassumptions for the development of Geoparks (project GAJA)], and Donatas Pupienis, Jaroslaw Kmita, Zbigniew Kowalski \& Vidas Mikulenas (Lithuania \& Poland) [Geotopes data base and its applications for geotourism in Polish-Lithuanian cross-border]. Together they outlined the main goals of the project under the auspices of the INTERREGIII/A initiative as being to determine the area of the geopark and to promote an understanding of its geographical and geological characteristics. To this end an atlas for environmental protection and territorial planning has been published and a data base constructed with 200 sites that can be used by tourists, schools, local communities, nature conservationists and land-use planners.

A poster session included details on 'Modeling of water systems for planning and sustainable development' by Aivars Spalvins, Janis Slagens, Romans Janbickis and Inta Lace (Latvia), 'Flint as a raw material of the prehistoric artefacts in Lithuania' by Valentinas Baltrunas, Bronislavas Karmaza, Dainius Kulbickas and Tomas Ostrauskas (Lithuania), 'Geoheritage of the great Nemunas loops, South Lithuania' by Bronislavas Karmaza and Algirdas Zuzevicius (Lithuania), 'Vulnerability of geological monuments in the Nemunas river valley' by Bronislavas Karmaza and Valentinas Baltrunas (Lithuania), and 'Heterogeneous aspects of protection and use of erratic boulders in North Eastern Poland and Lithuania' by Tomasz Krzywicki and Elzbieta Tolkanowicz (Poland).

There were two full day excursions to see localities in the cross-border Yotvings Belt. The Lithuanian day was to examine the 'Geodiversity of Dzukija and Suvalkija' and the Polish day to examine the 'Geodiversity of Suwalki region'.

The excursion in Lithuania, led by Albertas Bitinas and Alma Grigiene, gave an opportunity to see various aspects of the Quaternary cover in the area around and to the north of Druskininkai. Glacial and glaciofluvial deposits cover the largest part of Lithuania, varying from a few meters in thickness in the north to over 200 meters in the uplands. Up to $60 \%$ of groundwater used for supply as well as $98 \%$ of sand, clay and gravel resources come from these deposits. The first stop was to see the large, horseshoe shaped Raigardas valley formed about 5,000 years ago through the increased curvature of the Nemunas river. Pure water springs, such as the "Bobos Darzas" (stop 2) are found in thermo-karstic depressions resulting from postglacial melting of buried ice lumps in the glacial sands left by melting waters of the last glaciation. Terraces show that the thermo-karstic valley developed in several stages. Another interesting development in sandy sediments was the suffosian circus (stop 3). Here percolating water has created a void in the continental dune massif of $60 \mathrm{~m}$ in diameter and a depth of $30 \mathrm{~m}$. The spring at the bottom flows at the rate of 5 litres per second. Nearby (stop 4) was the 29.4 ha Bakanauskai Mire surrounded by sandy plains formed by ice melt water and $10-15 \mathrm{~m}$ high continental dunes. The lake, of thermokastic origin, is now only 4.2 ha in extent being overgrown by the Sphagnum mire and pine forest. There is very little active inland dune movement now through grass and tree growth. Stop 5 was at the Gaidziu Galas Dune where there is a hill of white sand that is still open and moving. Stop 6 at the Ula outcrop on the bank of the Ula River gave us an opportunity to see a section through $19 \mathrm{~m}$ of sandy succession of a number of different geological structures formed by meandering and braided water flows from meltwater of the last glaciation. These were overlain by fine grained eolian sands. Close by (stop 7) was the Ulos Akis spring emerging through the medium grained sand of the river terrace. Coming from inter-morainic horizons the water is clear, hydro-carbonaceous, magnesium and calcium rich and 80 C. Flowing at just over 21 per second, a small stream flows for $67 \mathrm{~m}$ before joining the Ulos River. Other stops took us to the popular tourist site of the Punia Mound at the confluence of the Nemunas River and the Punele Stream and the Ozku Pecius (Goat Stove) conglomerate outcrop exposed on the steep bank of the Verkne River. This conglomerate was formed when inter-till gravel, pebbles and sandy layers were cemented with calcium carbonate from ground water discharges during the Gruda and Baltija stadials of the Last Glaciation. The Lithuanian day excursion ended by visiting the information centre of the Regional Park of Nemunas Loops in Birstonas. The director of the park, Dalia Krizinauskiene, gave a guided tour of the centre.

The excursion in Poland was led by Marek Graniczny and Magdalena Czarnogorska. The first visit was to the Hydrological Observation Station in Sidorówka located in the glacial morainic upland in the eastern border of the Szeszupa Depression. Boreholes monitoring the groundwater show that the groundwater in the Quaternary deposits stabilises at about $24 \mathrm{~m}$. A climb to the summit of Cisowa mountain gave a view over the Suwalki Lowland Park. This cone-shaped mountain, known locally as Fugi of Suwalki, is an end moraine built from sand, gravel and small boulders. Another viewpoint in Smolniki gave views over the Szeszupa Depression where Baltic ice sheets covered the area during the Pomeranian phase. In the following Szeszupa sub-phase the retreating ice sheet created moraines, kames and eventually lakes. The local Hanicza lake is the deepest in Poland with a depth of $109 \mathrm{~m}$. The deep furrow was formed during the Vistulian (Weichselian) Glaciation and large amounts of glacial boulders line its coast. The next step was the Bachanowo boulders field; a geological landscape reserve established in 1972. About 10,000 erratic boulders are located here in four different horizons above the river originating from the outwash of glacial tills of the Wigry and Hanza subphases. Subsequently all the fine sediments were washed out by the river leaving the larger boulders. The nearby Rutka boulder field is also protected as an example of glacial pavement. The final visit was to the core storage of the Central Geological Archive of the Polish Geological Institute that was established during the prospecting for magnetite-ilmenite ores in north-eastern Poland.

The Volume of Abstracts of the Conference is accessible on the internet at http://www.lgt.lt/files/leidiniai/druskininkai. pdf

\section{Barry Thomas}

British Institute for Geological Conservation ProGEO Northern group

$U K$

bat@aber.ac.uk

\section{Jonas Satkunas}

Lithuanian Geological Survey ProGEO Northern group and IUGS-GEM Lithuania

jonas.satkunas@lgt.lt

\section{Marek Graniczny}

Polish Geological Institute

IUGS-GEM

Poland

marek.graniczny@pgi.gov.pl 